\title{
History Writ Large: Big-character Posters, Red Logorrhoea and the Art of Words
}

\author{
Geremie R. Barmé, Australian National University
}

In 1986, the Zhoushan-based artist Wu Shanzhuan worked with other recent art school graduates to create an installation called 'Red Humour' (hongse youmo 红色幽默). It featured a room covered in the graffiti-like remnants of big-character posters (dazi bao 大 字报) that recalled the Cultural Revolution when hand-written posters replete with vitriol and denunciations of the enemies of Mao Zedong Thought were one of the main cultural weapons in the hands of revolutionary radicals (Figure 1). It was an ironic attempt to recapture the overwhelming and manic mood engendered by the red sea of big-character posters that swelled up in Beijing from mid 1966 and developed into a movement to 'paint the nation red' with word-images during the second half of that year and in 1967. In the reduced and concentrated form of an art installation $\mathrm{Wu}$ attempted to replicate the stifling environment of the written logorrhoea of High-Maoist China (Figure 2).

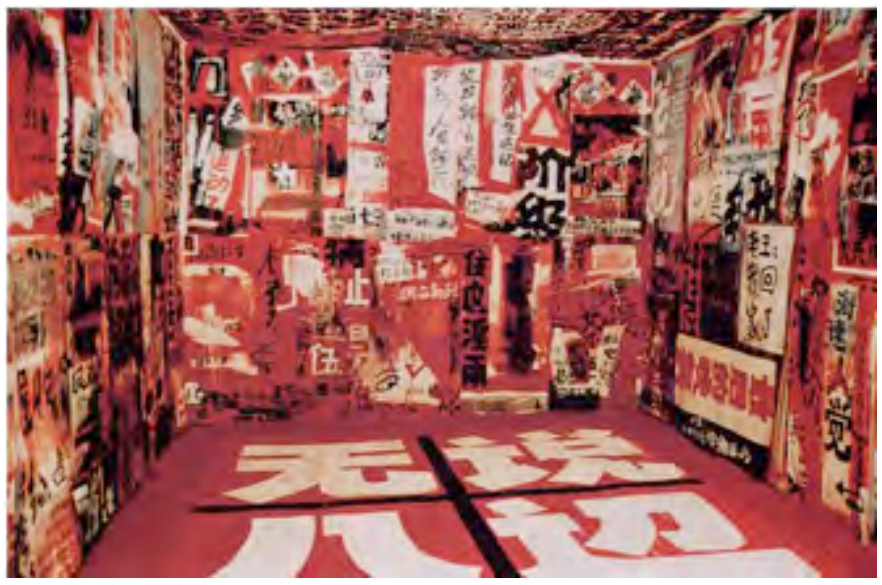

Figure 1: 'Red Humor,' Wu Shanzhuan. Source: Gao Minglu (2008) '85 Meishu Yundong—80 niandaide renwen qianwei, Guangxi shifan daxue chubanshe, Guilin, vol. 1. 


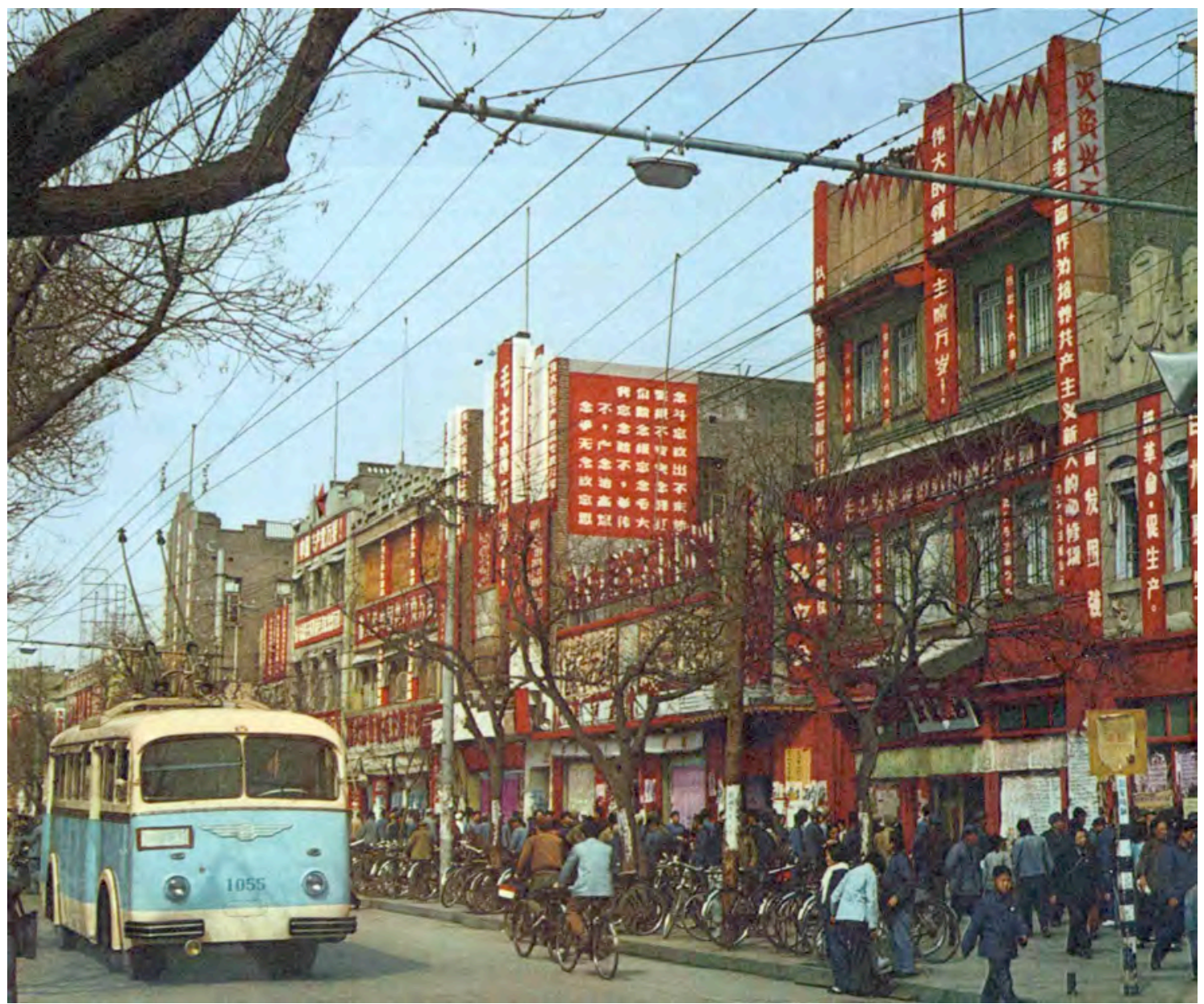

Figure 2: Red Sea, Beijing 1967. Source: Long Bow Archive, Boston.

As an irony-laden reprise of big-character poster culture, Wu Shanzhuan's 'Red Humor' could only convey an overall and absurdist sense of the big-character posters that played such a crucial role in the culture and politics of China's Cultural Revolution era (c. 19641978). In the bapo 八破 ('eight fragments' bricolage of the late-Qing era) style of his installation (Figure 3), a simple quotation of verbal extremism and abuse, Wu Shanzhuan offered a momentary reflection on the word, image, the wall and the maelstrom of the revolutionary excess and verbal outpourings of the period. But in so doing he also reduced what was a complex and unique medium - one that allowed for the articulation of vastly different views and rhetorical effects - to something akin to cultural wallpaper. Since the 1980s, Wu has had many emulators and 'avant-garde successors.' Reconsiderations and manipulations of the word in the logocentric political culture of China respond to the abiding power of the written and the formulaic (tifa 提法) in that environment, and they feed off the allure of dissent and the opportunities provided by the art market to reaffirm the aura of that which they would challenge. 


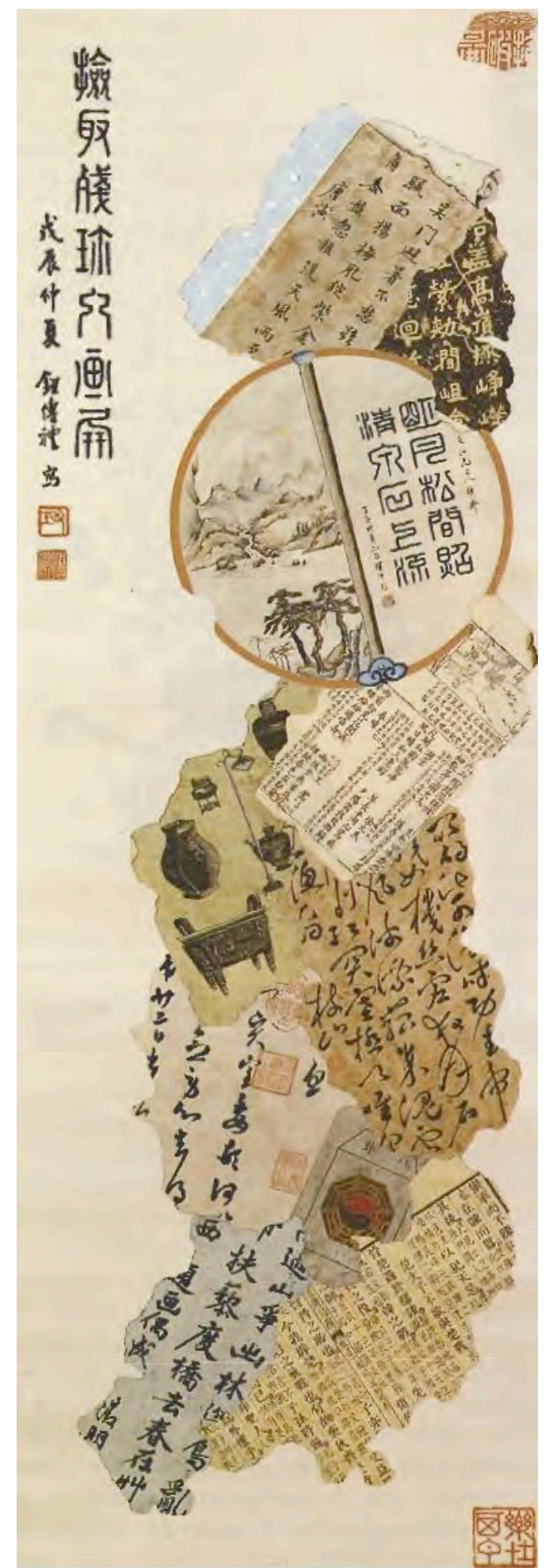

Figure 3: Eight-fragments Art. Source: Nancy Berliner,

'The Eight Brokens, Chinese Trompe l'Oeil Painting,' Orientations, February 1992.

This essay considers the legacies of the word made image in China, legacies in which metaphor and the written Chinese character $z i$ 字, caricature and politics, text and subtext are engaged in a constant and complex exchange. 
Characters are the paintings of the heart 字心畫也

- Yang Xiong, Western Han dynasty 西漢楊雄

The person is reflected in his compositions 文如其人

The person is reflected in his calligraphy 字如其人

The person is reflected in his painting 畫如其人

\section{Remembering the Xinhai year of 1911}

The year 2011 marked the anniversary of the formal start of China's century of revolution. It was, and remains, a revolutionary era in terms of politics, society and culture. The discussion of Xinhai, revolution and reform are not merely matters of interest to nitpicking historians or contemporary commentators on the historical parallels between a dynastic system in decay and the hide-bound one-party state of China today. As Chinese historians and thinkers in disparate intellectual camps have noted, trends to affirm revolutionary tradition, failed (or foreshortened) radicalism, as well as nostalgia for social hierarchy, re-imagined Chinese values, along with political positions at various points on the spectrum from social democracy to radical neo-liberalism continue to inform and enliven debates in China (Xiao 2012). These debates are vital today, as they were in the Xinhai decade - that period from the New Policies of the Qing to the New Culture Movement, and again during various eras since then. For behind China's search for wealth and power has always lurked a more existential quest, one that enlivens the realm of ideas and art in complex and contradictory ways: the search for meaning and ways to express that search - be it through the written, or visual, or in the overlapping nexus of the two.

For the Chinese world, the past is not a foreign country; many of the major issues related to ideas and culture, thought and history remain on the agenda of political and social change today. The issues at the heart of China's revolutionary century-social justice, political participation, basic freedoms, material welfare, national strength - have valence far beyond the country's borders. In an era of a global China, one in which economics and trade, political behaviour and cultural ambition now enjoy an embracing reach, the continued discussion and understanding of historical moments in that country's modern era are relevant in new ways.

Even in the late-nineteenth century the Chinese character and the written language were finding their way into art, albeit commercial Treaty Port art. The most noteworthy genre was that of 'Eight Fragments' (bapo 八破) art. These works were produced by anonymous 
artists (Figure 4). They feature texts - including Chinese characters and Manchu, epigraphy and calligraphy - in a strewn, cut-up constellation. Generally framed as traditional Chinese scholar-artists scrolls, they are a particular form of early modern or late-traditional art. Eight Fragments art appeared in the latter decades of China's last imperial dynasty, from roughly the 1870s. As the art historian and bapo expert Nancy Berliner has said of this kind of Sino-bricolage avant la lettre, such works were made as paintings as well as being featured as designs on porcelain and various objects (Berliner 1992: 61, 62, 63). The creation of that liminal world, one that existed between the Chinese literary hinterland and the Treaty Ports that saw the creation of bapo works was centred on the entrepot of Shanghai. They reflect also the fractured written world of China's late tradition through artistic reinvention.

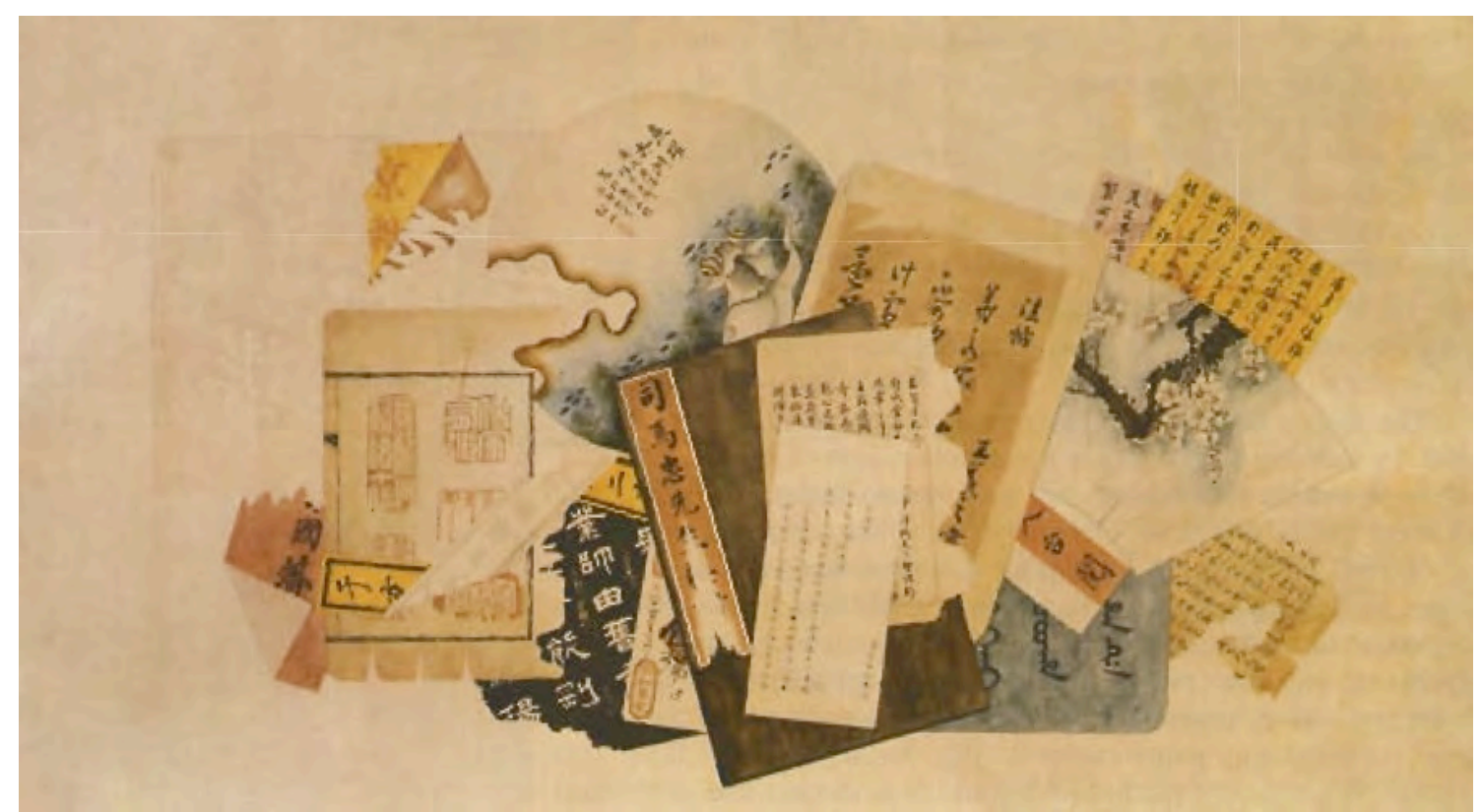

Figure 4: Eight-fragments Art. Source: Nancy Berliner, 'The Eight Brokens, Chinese Trompe l'Oeil Painting,' Orientations, February 1992.

Bapo works were produced with greater frequency in the declining years of the Qing dynasty in the late-nineteenth century and then following the 1911 Xinhai Revolution. In a world in which canonical texts - the Confucian classics that had defined the Chinese world, political power, social elites and the cultural landscape for over a millenniumwere in tatters, these works reflected the riven reality of their times.

When an earlier version of this paper was presented at the conference 'Word \& Image, East \& West,' our venue was at the Art Gallery of New South Wales, Sydney Australia. At the time the gallery was holding an exhibition entitled 'The Mad Square: Modernity in 
German Art, 1910-37.' The show featured one work that also appears in the promotional materials for the show by Ludwig Meidner (1884-1966). Begun by the artist in the first year of China's Republic, 1912, Meidner's 'Apocalyptic Landscapes' would later be celebrated for their prophetic vision not only of the chaotic modern city but also of Germany reduced to rubble in war, one that would visit destruction from the air on the cities of that country during the last years of WWII (Figure 5).

The cultural and architectural critic of The Sydney Morning Herald, Elizabeth Farrelly, had the following to say of the exhibition:

The Mad Square's rooms lead you into hell, hold you down and tickle you until your tears curdle into laughter...

But The Mad Square is more than that. Much more. It's about seeing. Really_frankly, fearlesslyseeing. (Farrelly 2011) (Figure 5)

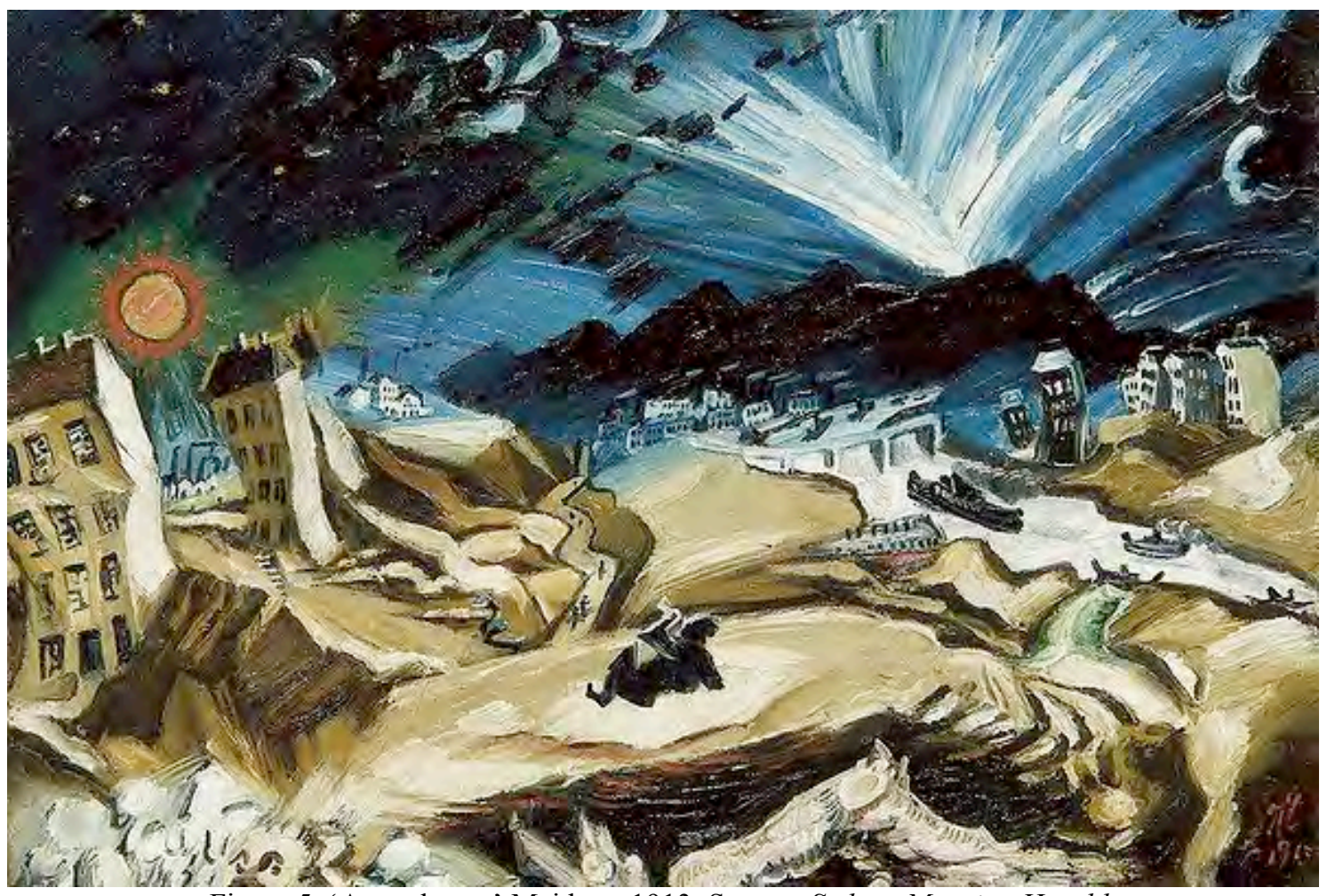

Figure 5: ‘Apocalypse,' Meidner, 1913. Source: Sydney Morning Herald.

In this centenary year of China's 1911 Xinhai Revolution, there is another image of destructive energy that prefaced my spoken presentation. The Beijing-based AustralianChinese artist Guo Jian created a diorama, a large-scale work that he titled 'Demolition and Forced Relocation' (Chaiqian 拆迁) (Figure 6). He says of the piece that: “拆迁就是一 场战争。娱乐让我们无所畏惧, 曲直不明, 放肆和骄横终将被自己的挖掘机掘烂。' (Demolition and 
forced relocation is a battle. We have been entertained into fearlessness; there is naught, neither straight nor bent. Wanton arrogance is undone by its own machines of destruction).

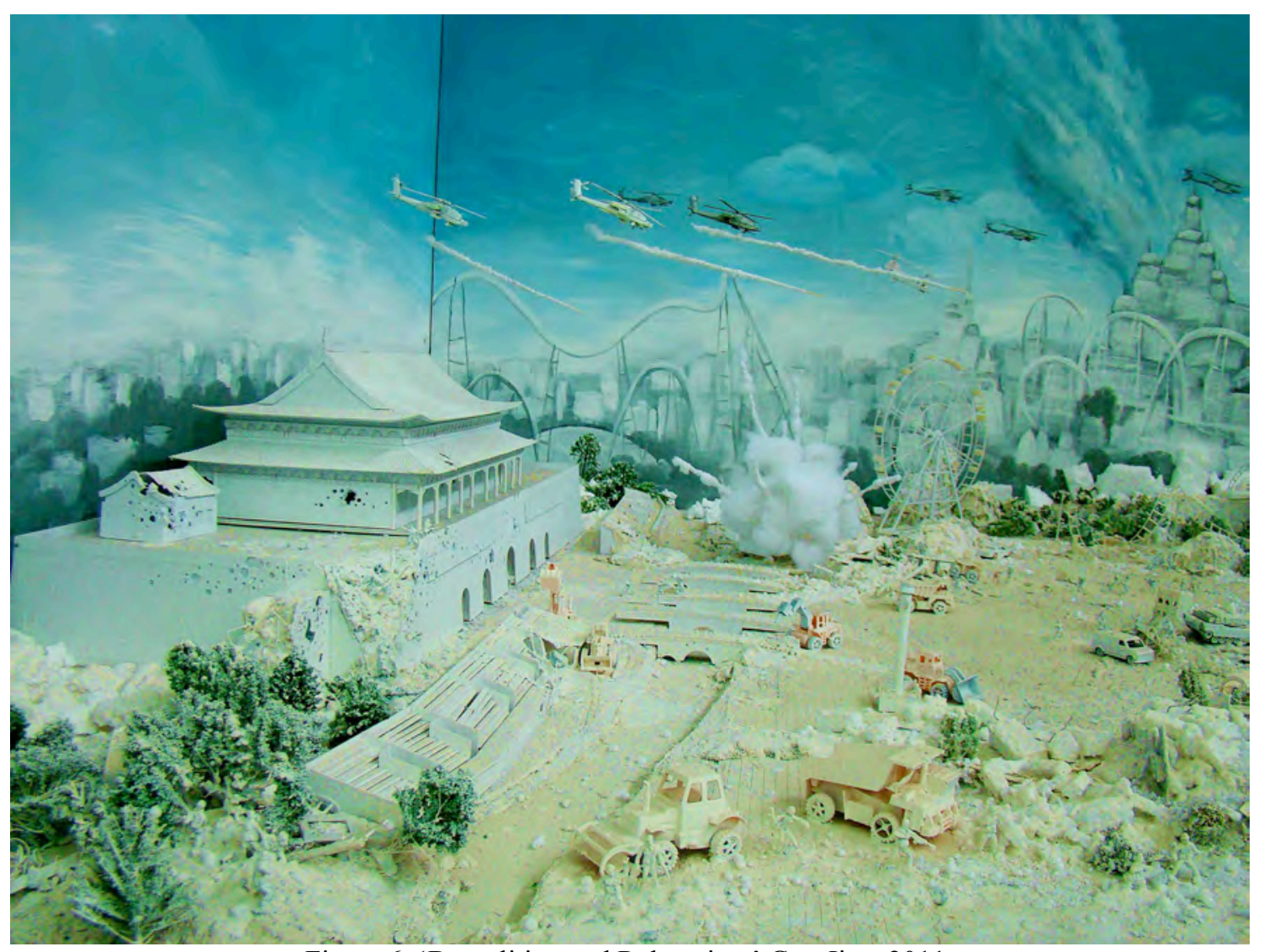

Figure 6: 'Demolition and Relocation,' Guo Jian, 2011.

Source: China Heritage Quarterly, September 2011.

I will return to the idea of 'demolition'—chai 拆—a word that in Chinese is deconstructive in its very nature. For not only is the character chai scrawled on walls and buildings to mark sites destined for demolition; it is also the word used to describe the act of making something understood as well as the act of disaggregating a Chinese character, either in written or verbal form, and explicating it or reordering it. To chai zi 拆字 is to dismember a character, to reduce it to its component parts, to open it for redeployment, reinterpretation and re-imaging, be that as a new word, concept or possibility.

\section{An elite art in the service of politics}

Learning how characters are put together, about their constituent parts, those elements that have meaning in and of themselves, those that are pictographic in some real or abstract way, or those that have some phonetic significance is a fundamental part of the acquisition of an understanding of how Chinese works as a language, a writing system and a world of 
significance. With that learning - for Chinese and non-Chinese alike - the stroke and calligraphic line often play a crucial role (Figure 7).

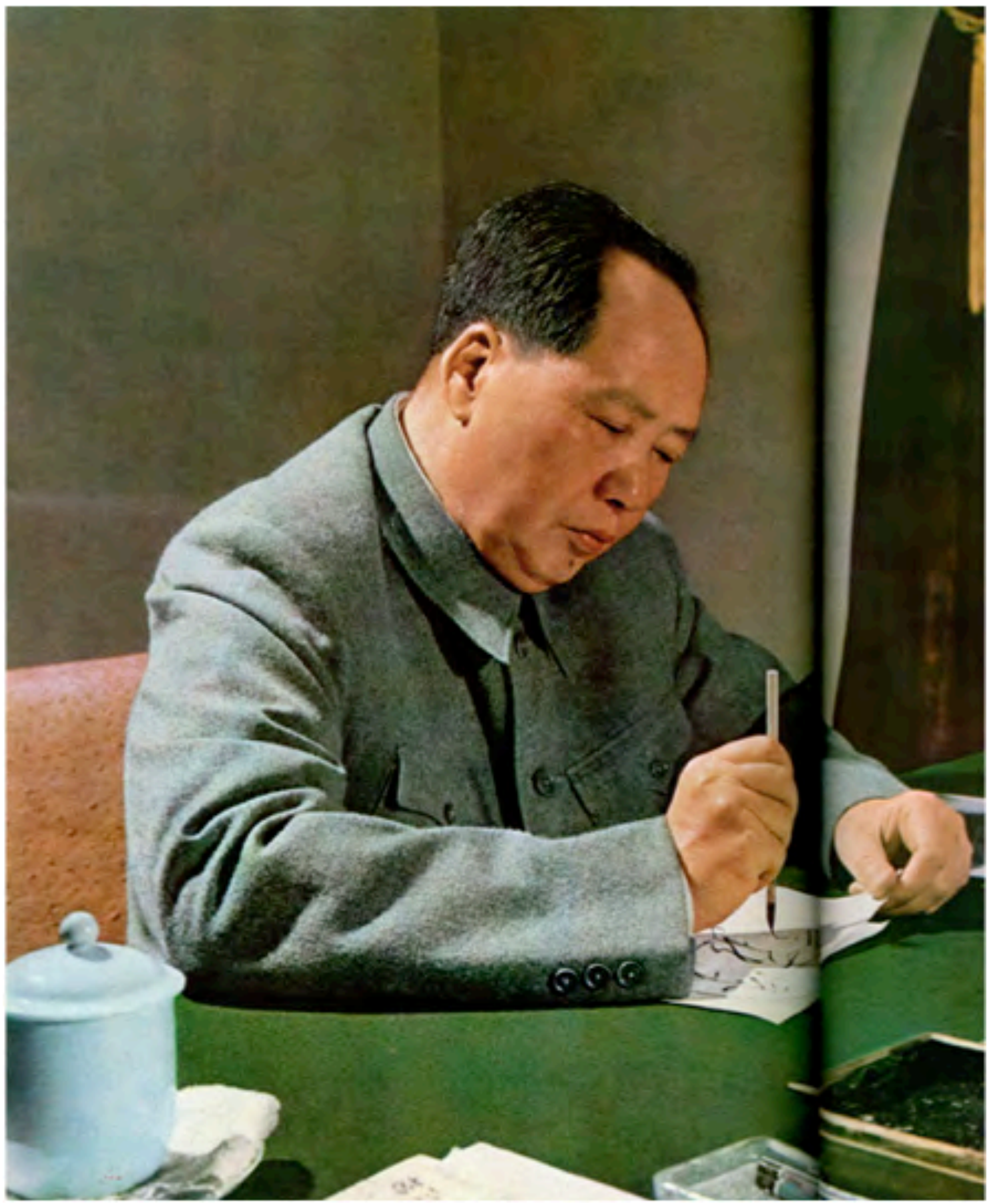

Figure 7: Mao Zedong at his desk. Source: Long Bow Archive, Boston.

Calligraphic work written for private display and the appreciation of connoisseurs has a venerable tradition in China (Ledderose 1970; Murck and Fong 1991). For over a century street politics saw calligraphy used as a cheap, convenient and popular means for communicating slogans, short messages and otherwise banned ideas. Anonymous protest, calls to arms, revelations, exhortations and denunciations could all be written up using the 
traditional brush, ink and paper and posted with facility on walls in cities, towns or even villages. These slogans and exhortations could act as a form of public outcry; they were posted outside government offices; they could give expression to interrogations on the doors of publishers, direct accusations at miscreants, appeal for justice to the courts or the police, or just give voice, in written form, to personal grievances.

The political scientist Richard Kraus has noted: 'The reconstitution of the bond between art and politics is encapsulated in the transformation of calligraphy from a private to a public art. Calligraphy in the People's Republic [of China] publicizes relationships that were conventionally private by using an art that was traditionally personal' (1991: 169). Kraus goes on to comment on how cultural and political authority were expressed by New China's leaders when they wrote calligraphic inscriptions for newspaper mastheads, or institutions such as factories and schools. Part of the reconstitution of calligraphy redirected what had been an elitist cultural form into the realm of mass media politics.

Calligraphy would also be central to popular protest. Different from the grand sweep of the leader's brush were the demotic calligraphic works that would feature in Chinese politics and life for over four decades: the dazi bao, literally 'big-character poster.' The dazi bao as a vehicle for informal and irregular popular communication first featured prominently during the years of the Japanese War from the late 1930s. Some of the earliest dissenting voices within the Communist Party chose wall posters (bibao 壁报) already a common form of agitprop popularized during the Republic - as a means for expressing their views. A number of writers and artists at the Communist Party's wartime base in Yan'an, Shaanxi province, posted satirical essays, poems and cartoons on walls. They used these artistic, written and literary forms to question the inequalities of the proffered life under the party and offered 'internal' criticisms of a progressive political cause that was spoken of only in positive and laudatory terms by the party media.

The new agitprop tradition of slogan writing, wall-poster notices carrying political information, or new directions in mass propaganda created a format — and a calligraphic fluency - that could be utilized by people of all social strata for political expression, no matter how basic. The act of composing a wall poster, usually with an audience of one's supporters or fellow authors (the poster might often carry a collective message), and then posting it either openly or covertly at night, was a new form of publication. 
The Communist Party Chairman Mao Zedong approved of this form of public political expression during the early years of the People's Republic, which was founded in 1949. He would eventually even praise the use of the 'four greats' or four big rights (si da 四大) that gave (prescribed) license to people to speak out, to air their views fully, to hold great debates, and to write big-character posters. In the mid-1950s posters reappeared, this time on walls in factories, educational institutions and elsewhere during the Hundred Flowers campaign when for a time the Communist Party urged disgruntled citizens to air publicly their complaints about the status quo. Workers as well as the urban elites used calligraphic posters to express themselves. Special woven mats were attached to wooden frameworks thrown up as temporary walls and poster alleys in factories, government office compounds, schools and universities for the posting of dazibao. They were avidly read and 'broadcast' by people who acted as individual scribes. They would transmit the content of the poster privately or back in their own work place by copying it out and posting it anew (Figure 8).

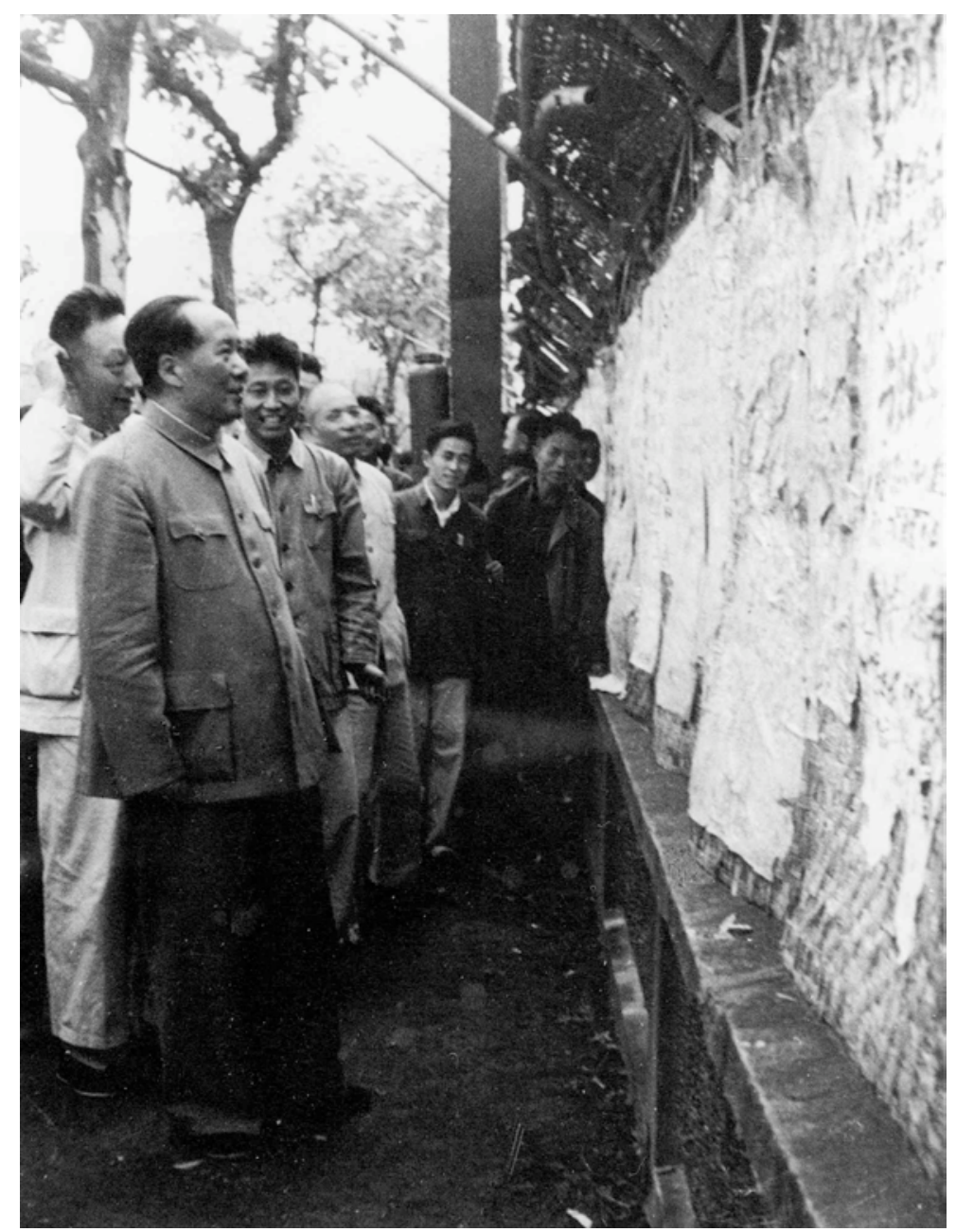

Figure 8: Mao Zedong viewing big-character posters in the 1950s. Source: Long Bow Archive, Boston. 


\section{An effective weapon}

The outspokenness of the Hundred Flowers period, and the flurry of big-character posters, shocked party rulers, and as a result, 1957 saw a period of repression and silence. For nearly a decade, although rogue individuals might dare to air solitary grievances, the poster was for the main part only used to extol party policy. But the big-character poster would reappear with devastating effect when Mao, sidelined for his more radical economic and political policies, encouraged popular protest against the party mainstream in the mid-1960s.

During 1965 and the first half of 1966, Mao argued that dangerous reactionaries were in control of the country's direction and the party media. He supported a rebellion against the entrenched ruling party of which he was titular head in an attempt to regain ideological control of the party and once more dominate state policy. He did so through a series of guerrilla-like feints and moves. In particular, he and his supporters saw the 'four greats,' among them big-character posters as 'effective weapons' (you li wuqi 有力武器). As many authors have noted, posters written by anonymous authors or put up overnight in prominent places for mass delectation were a kind of propaganda tool that effectively bypassed the traditional party-controlled media at a time of intense political infighting and contestation. Furthermore, through the act of copying, reproduction and dissemination these posters acquired a unique mystique. Li Rui, a secretary of Mao's for a short period in the 1950s, quoted the Chairman as having remarked: 'Many things cannot be resolved by laws alone. Laws are a dead letter, no one is intimidated by them. But up goes a bigcharacter poster, the masses carry out a denunciation followed by a struggle meeting, and that's more effective than any law' (Li Rui 1998: 290).

On 25 May 1966, a number of student and teachers at Peking University put up a massive big-character poster at the soon-to-be famous university 'triangle' (sanjiaodi 三角地), a popular gathering place on the campus (Figure 9). Although the text of the poster was prolix and dry, this informal document attacked both the university leadership and members of the municipal party committee that ran Beijing itself, a previously imperious, and impervious, group of high-level bureaucrats. Following Mao's intervention the text of the poster was broadcast to the nation and then published in the press on 1 July, just as the capital's media (press and radio) apparatuses were being taken over by supporters of 
Mao's own ideological line in what was known as the Great Proletarian Cultural Revolution.

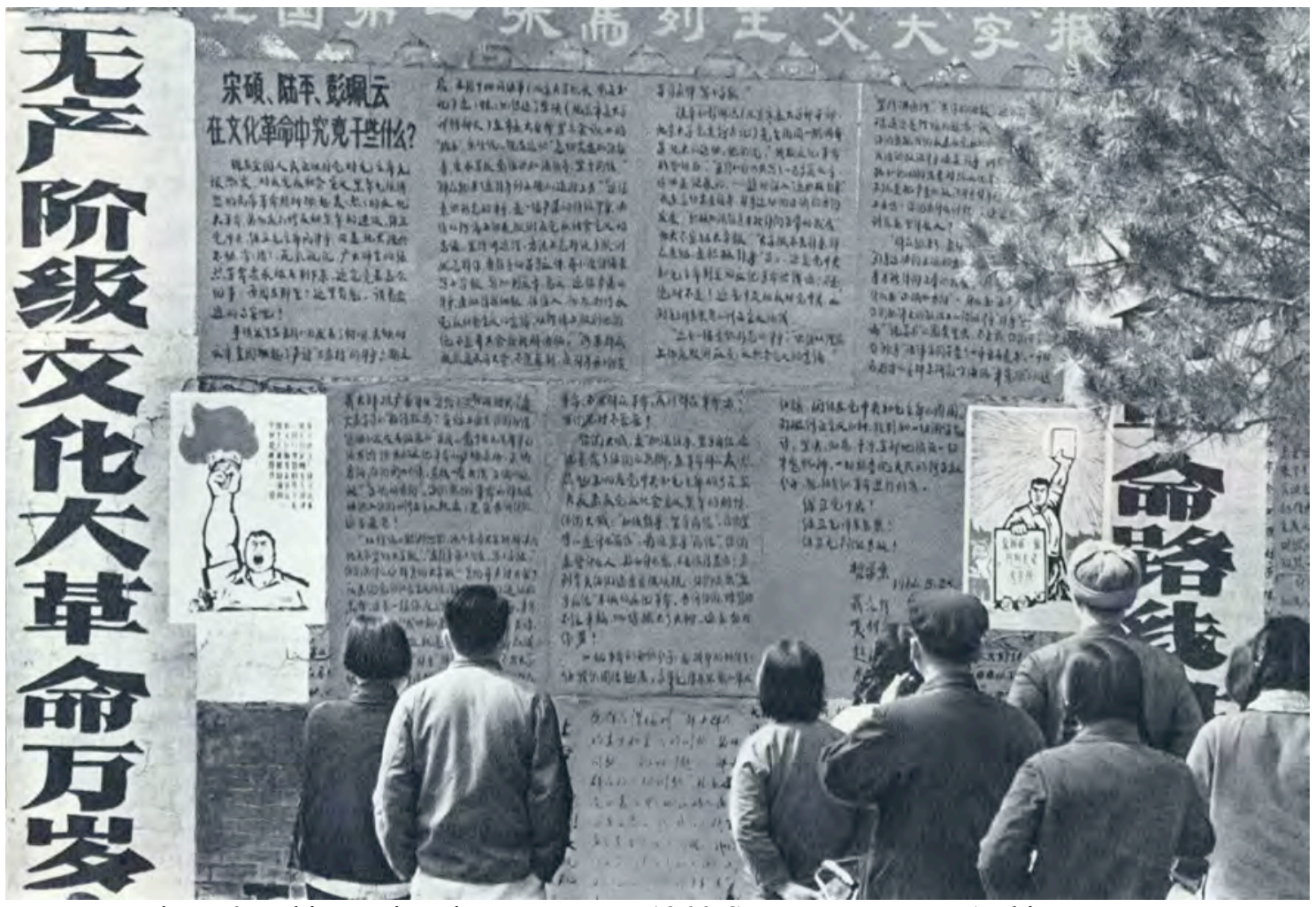

Figure 9: Peking University Poster, May 1966. Source: Long Bow Archive, Boston.

Enraged by municipal and school leaders who had attempted to direct and dampen the movement to put ideological training at the forefront of education, the authors of the Peking University poster were particularly incensed by repeated admonishments from their local party leaders that the political situation did not warrant the use of posters or mass agitation. 'Mini-posters' (xiaozi bao 小字报) generated by group discussion and displayed discretely in classrooms or dormitory corridors were, however, deemed permissible. However, the broadcasting of the Peking University poster ordered by Mao sanctioned public criticisms of school authorities and inspired young people to write their own posters airing grievances about university governance, the direction of educational policy and even the fate of China's revolution.

The style of the 25 May Peking University poster was widely emulated. The authors employed a militant style of language popularized by the Communist Party in the war. They used it to provide their readers with pejorative quotations of their enemies; they posed rhetorical questions and offered their own answers; they enumerated a phrase-byphrase rejection and ridiculing of their enemies' arguments - and it was all expressed in a 
tone of urgency and moral outrage. The vitriolic language of the original poster and its imitators were matched by cartoons and caricatures of ideas, and eventually of party leaders, that came under attack, or who would fall from favour.

At the time, the pro-Mao party media carried the following message about the new streetside form of written protest:

\begin{abstract}
Big-character posters are a powerful weapon of these young fighters to attack those in authority who are openly or covertly taking the capitalist road, as well as all ghosts and monsters. Like sharp swords and daggers, these big-character posters pierce the enemy's vulnerable points, wound the enemy where it hurts, strengthen the resolve of revolutionaries and destroy the enemy's prestige. This is why they are warmly welcomed by the revolutionary masses, who hasten to copy them down and spread them. (Chinese Literature 1966: 42-43)
\end{abstract}

\title{
The rise of the Red Guards
}

The revolutionary agitation sanctioned by Mao was by no means restricted to university campuses. Over the spring and summer months of 1966, a small group of secondary school students at elite institutions in the university district of Beijing also gathered to discuss politics and the significance of the charged political atmosphere. Because of their family circumstances - among their number were the children of party leaders-some of them had access to classified government materials or were privy to the rumour-mill of gossip that circulated among high-level cadres. As vague cultural attacks on bourgeois thinking and political incorrectness became more focussed in the Shanghai media — as yet Beijing was only reprinting some of the cultural broadsides that Mao had his supporters publish in Shanghai- these young people felt emboldened to criticize their own school leaders and teachers.

They believed that the dangerous bourgeois and anti-party sentiments being exposed in the media were also evident in their schools. They felt that their formerly respected school leaders were in fact part of a vast conspiracy within the party hell-bent on sidelining the revolution in favour of capitalist policies that would betray China's socialist destiny. The criticisms they made of their high-school teachers and local party leaders took the form of mini-posters, short incendiary essays that were pasted on class or school noticeboards. During May 1966 the students at one particular institution, Tsinghua University Attached Middle School, debated the direction of China's revolution among themselves; they decided that it was time to voice their concerns collectively. They chose for their ad hoc group a name that one of their fellows had been using to sign his mini-posters. That 
student, Zhang Chengzhi, simply referred to himself as a 'Red Guard' (hong weishi 红卫士, this was subsequently changed to hong weibing 红卫兵, since it was felt that the word 'shi' \pm , which also means 'literary scholar,' was tainted by its feudal associations).

On 27 May, the classmates gathered at a favourite spot: the isolated ruins of the marble, Jesuit-designed Western Palaces of the Garden of Perfect Brightness. The gardens were a detached palace dating from the height of the Qing dynasty that had been laid waste following the invasion of the imperial capital by an Anglo-French force in 1860 during the troubled negotiations over the treaty that concluded the Second Opium War. The ruins, a major site of patriotic remembrance for modern Chinese, were situated next to the campus of Tsinghua Middle School. At that gathering, the group decided to call themselves 'Mao Zedong's Red Guards' and they swore a collective oath to protect Mao Thought and fight for world revolution. Now they too would write big-wall posters. Their first poster, which was pasted up on 2 June, the day after the Peking University poster was broadcast on the radio, garnered over one hundred signatures of support. Thereafter, members of the nascent rebel group went on to write a number of critiques of their school, as well as of the party's overall educational policies and ideological training. Three of these essays that carried the title 'Long Live the Proletarian Revolutionary Spirit of Rebellion!' (Wuchanjiejide geming zaofan jingshen wansui! 无产阶级的革命造反精神万岁!) would become famous.

\section{The rhetoric of rebellion}

Drafted by Luo Xiaohai the three essays that comprised 'Long Live the Proletarian Revolutionary Spirit of Rebellion!' were replete with the kind of militaristic hyperbole favoured by pro-Mao propagandists and writers - in particular Chen Boda and Yao Wenyuan, both of whom were increasingly influential in the Cultural Revolution movement. To this strain of denunciatory vitriol Luo added elements of playful (although deadly) metaphor by introducing the figure of the fictional hero Monkey King (Sun Houwang 孙猴王, also known as Sun Wukong 孙悟空) to the text. A favourite figure also with Mao Zedong - the chairman who recognized the unbridled side of his personality even compared himself to the irascible rascal Monkey-Sun Wukong was the wilfully rebellious but lovable rogue who featured in Wu Cheng'en's sixteenth-century novel Journey to the West (Xiyou $\mathrm{Ji}$ 西游记). Monkey's popularity only increased when a film version of a stage play about him defeating the 'White-boned Demon' was released in 
1960 (Sun Wukong san da baigujing 孙悟空三打白骨精). This was followed in 1964 by a cartoon feature film, Uproar in Heaven (Danao tiangong 大闹天宫) (Figure 10).

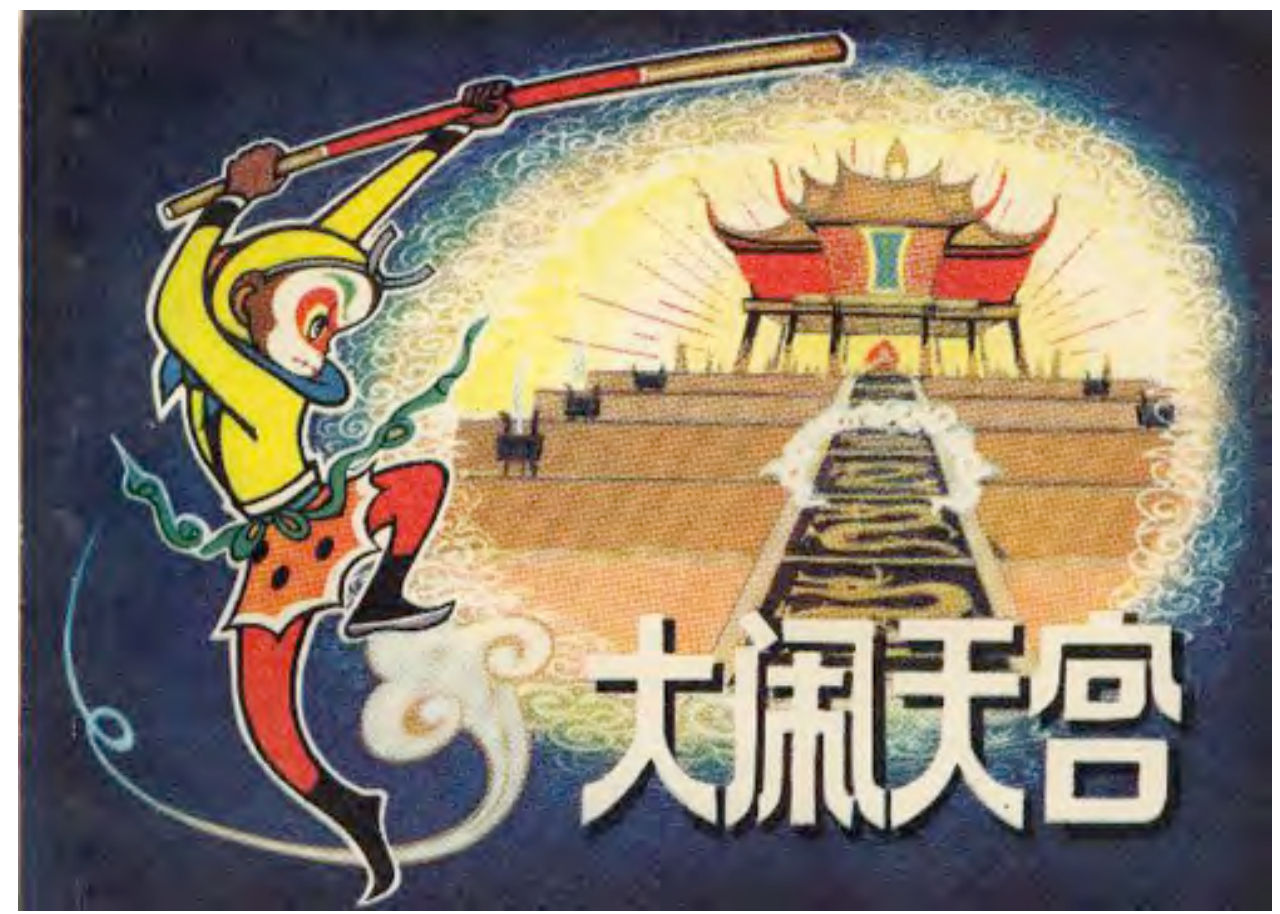

Figure 10: Poster for the 1964 feature film, Uproar in Heaven.

Source: Long Bow Archive.

Luo wrote in the final paragraph of the first of his three essays on justified rebellion against the status quo that:

Revolutionaries are Monkey Kings, their golden rods are powerful, their supernatural powers farreaching and their magic omnipotent, for they possess Mao Zedong's great invincible thought. We wield our golden rods, display our supernatural powers and use our magic to turn the old world upside down, smash it to pieces, pulverize it, create chaos and make a tremendous mess, the bigger the better! Today we must rebel against Tsinghua Middle School, rebel in the extreme, rebel to the end. We must create great revolutionary uproar in heaven and kill our way to a new proletarian world!

革命者就是孙猴子, 金筷棒厉害得很, 神通广大得很, 法力无边得很, 这不是别的, 正是战 无不胜的伟大的毛泽东思想。我们就是要抡大棒、显神通、施法力，把旧世界打个天翻地， 打个人仰马翻，打个落花流水，打得乱乱的，越乱越好! 对今天这个修正主义的清华附中， 就要这样大反特反, 反到底! 搞一场无产阶级的大闹天宫, 杀出一个无产阶级的新世界!

Here Luo's language took a cue from a poem written by Mao Zedong in reply to a verse by the pro-party littérateur Guo Moruo in 1961:

A thunderstorm burst over the earth,

So a devil rose from a heap of white bones.

The deluded monk was not beyond the light,

But the malignant demon must wreak havoc.

The Golden Monkey wrathfully swung his massive cudgel,

And the jade-like firmament was cleared of dust. 
Today, a miasmal mist once more rising,

We hail Sun Wukong, the wonder-worker.

一从大地起风雷，便有精生白骨堆。

僧是愚讯犹可训, 妖为鬼蜮必成灾。

金猴奋起千钧棒，玉宇澄清万里埃。

今日欢呼孙大圣, 只缘妖雾又重来。(Mao 1976: 41)

Although he couched his meaning in the highly allusive language of classical Chinese poetry, in his verse Mao was referring to the ideological contestation between China and the Soviet Union in the years following the Soviet party leader Nikita Khrushchev's denunciation of Stalin in 1956. The Sino-Soviet split of 1961 occurred when the two socialist giants fell out over issues related to ideological differences (Mao accused the Soviets of betraying Stalin, reneging on party principles and lurching towards 'revisionism') and defence arrangements. That split fed into Mao's fear that China would go the way of the Soviet Union and betray policies based on class struggle in favour of economic enrichment. These concerns directly influenced the Chairman's decision to launch a 'cultural revolution' aimed at reviving the rebellious spirit of the nation and preventing it from backsliding.

\section{'Bombard the headquarters!'}

The Red Guards were able to pass a copy of two of the three parts of 'Long Live the Proletarian Revolutionary Spirit of Rebellion!' to Jiang Qing, Mao's wife, at a public rally on 28 July 1966. By then the Chairman's wife was playing an important intermediate role in fomenting the Cultural Revolution uprising. They did not have to wait long for a response. On 1 August 1966, Mao wrote a note of support for the newly formed Red Guards. Said to be a letter addressed to the Red Guards the document was circulated among members of the party leadership that was meeting in Beijing to discuss the unfolding political upheaval. Shortly thereafter, Mao's 'letter' - a text that was never formally sent to the Red Guards, its contents only ever having been read to them by a party leader - was broadcast on Central People's Radio. Coming as it did at a time of such political drama Mao's support for the small group of Red Guards at Tsinghua Middle School had a momentous impact. Within a short period Red Guard groups appeared in schools throughout China. They swore to pursue a radical ideological agenda that would see the fundamental structure of the party-state itself threatened. 
At this crucial juncture in China's modern political life the big-character poster, a medium that combined art and writing, image and text, politics and activism, would now coalesce into an ideological weapon with devastating effect. At a crucial meeting of central party leaders - the Eleventh Plenum of the Eighth Party Congress - convened in Beijing in early August shortly after Mao had declared his support for the Red Guards, the formal program for the unfolding political movement was being finalized. The meeting presaged what would become a vast purge of the Chairman's real and imagined bureaucratic and ideological enemies. During that meeting Mao scribbled a few pencilled lines in the margins of the newspaper Beijing Daily published on 5 August. These notes were subsequently transcribed by one of his secretaries and emended, again in pencil, by the Chairman (Figure 11). The resulting document was called 'Bombard the Headquarters' (Paoda silingbu 炮打司令部) and it carried the subtitle 'my own big-character poster' (wode yizhang dazibao 我的一张大字报). A printed text of this 'poster' was circulated to party leaders attending the closed-door conference.

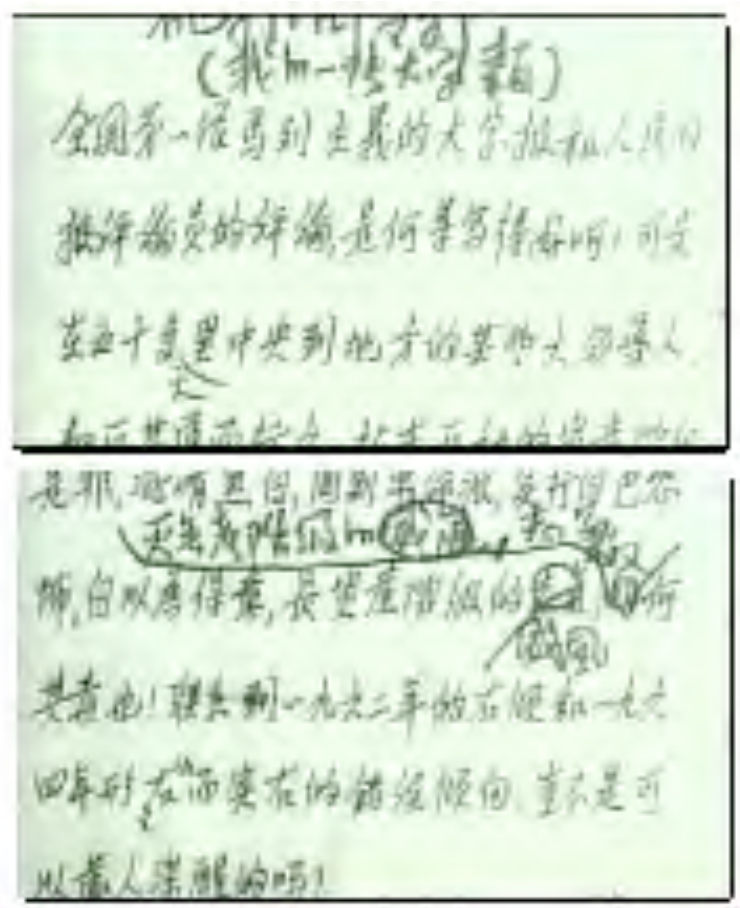

Figure 11: Mao's corrections to his secretary's transcript of the text of 'Bombard the Headquarters.' Source: Long Bow Archive, Boston.

In this extraordinary document Mao referred once more to the big-character poster that had appeared at Peking University on 25 May. He declared that: 'China's first MarxistLeninist big-character poster and Commentator's article on it in People's Daily are indeed superbly written!' He went on to say: 
Comrades, please read them again. But in the last fifty days or so some leading comrades from the central down to the local levels have acted in a diametrically opposite way. Adopting the reactionary stand of the bourgeoisie, they have enforced a bourgeois dictatorship and struck down the surging movement of the great Cultural Revolution of the proletariat. They have stood facts on their head and juggled black and white, encircled and suppressed revolutionaries, stifled opinions differing from their own, imposed a white terror, and felt very pleased with themselves. They have puffed up the arrogance of the bourgeoisie and deflated the morale of the proletariat. How poisonous! Viewed in connection with the Right deviation in 1962 and the wrong tendency of 1964, which was 'Left' in form but Right in essence, shouldn't this make one wake up?

全国第一张马列主义大字报和人民日报评论员的评论，写的何等好啊! 请同志们重读这张大 字报和这个评论。可是五十多天里, 从中央到地方的某些领导同志, 却反其道而行之。站在 反动的资产阶级立场上, 实行资产阶级专政, 将无产阶级轰轰烈烈的文化大革命打下去, 颠 倒是非，混淆黑白，围剿革命派，压制不同意见，实行白色恐怖，自以为得意，长资产阶级 的威风, 灭无产阶级的志气，又何其毒也! 联系一九六二年的右倾和一九六四年的形'左'而实 右的错误倾向，岂不是可以发人深醒的吗? (Mao 1967)

Here Mao spoke of 'leading comrades' having enforced a 'bourgeois dictatorship' on the city's universities by clamping down on calls for a further ideological revolution in education. Mao thus created a series of stark binary opposites after which he proceeded to employ historical analogy that he capped off with a pointed, somewhat sardonic, dismissal of his opponents. He said of those who had attempted to quell the student rebellion in the universities: 'They have stood facts on their head and juggled black and white, encircled and suppressed revolutionaries, stifled opinions differing from their own, imposed a white terror, and felt very pleased with themselves.' He used imagery that invoked the period of the 1920s and 1930s when, following the split between the Nationalist and Communists, a 'white terror' launched by the Nationalists saw the detention and execution of numerous revolutionaries.

Composed in a tone that commingled intimacy with admonition, Mao Zedong's 'bigcharacter poster' appears to be a letter of support for the students of Peking University, and the Red Guards whom they had inspired. In reality, the 'poster' was an internally circulated declaration of war on a shadowy clique that Mao assumed lurked at the heart of the Communist Party, one that he felt was threatening the very course of the Chinese revolution.

\section{Painting the world red}

The text of Mao's 'poster,' as well as the 'image' associated with the text achieved an iconic status overnight. Since big-character posters - an agitprop art form that had been turned into a powerful political tool for non-official communication — had achieved a new prominence in the proceeding months, people readily imagined that a text issued by the 
ultimate revolutionary authority in the country dubbed a big-character poster must have actually been written with a calligraphic brush on paper and pasted up on a wall (Figure 12). And although the mass dissemination of the text played a strategic role in placing Mao on the side of rebellious students and teachers who had been putting up posters on campuses in the capital from May that year (and often suffering from punishments meted out by strict party leaders in their schools and the work teams sent to direct the unfolding revolution in education that initially was at the heart of the Cultural Revolution), in reality unlike those posters Mao's phantom poster was not written with a brush dipped in ink; it was never posted on the walls of the party compound of Zhongnan Hai, as many had assumed; nor indeed was it ever made into a real poster. Nevertheless, 'Bombard the Headquarters' remains the quintessential Ur-big-character poster of the Cultural Revolution era. After the text of the 'poster' was broadcast and carried in papers throughout the country, art works (themselves predominantly posters) quickly appeared that showed Mao in a military uniform, writing-brush in hand, penning the now-famous 'big-character poster' in red ink (Figure 13).

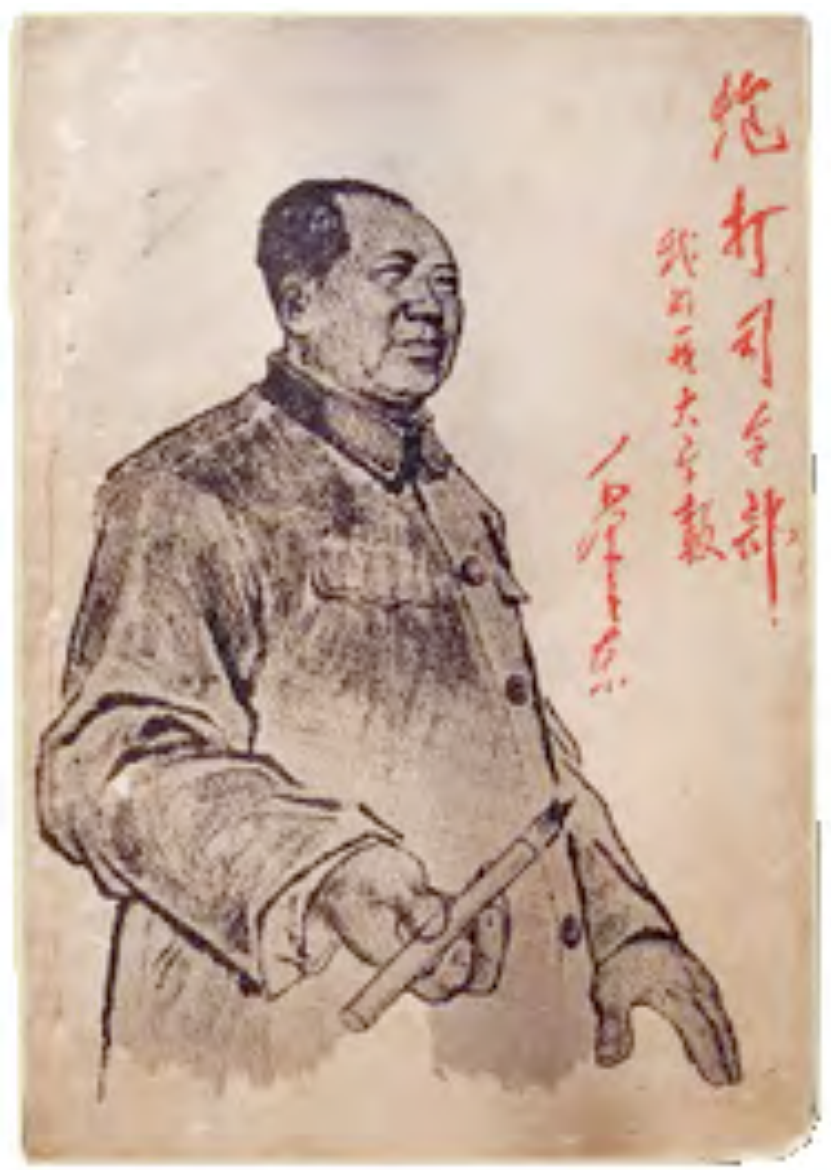

Figure 12: Poster of Mao and 'Bombard the Headquarters' c. 1967. Source: Long Bow Archive, Boston. 


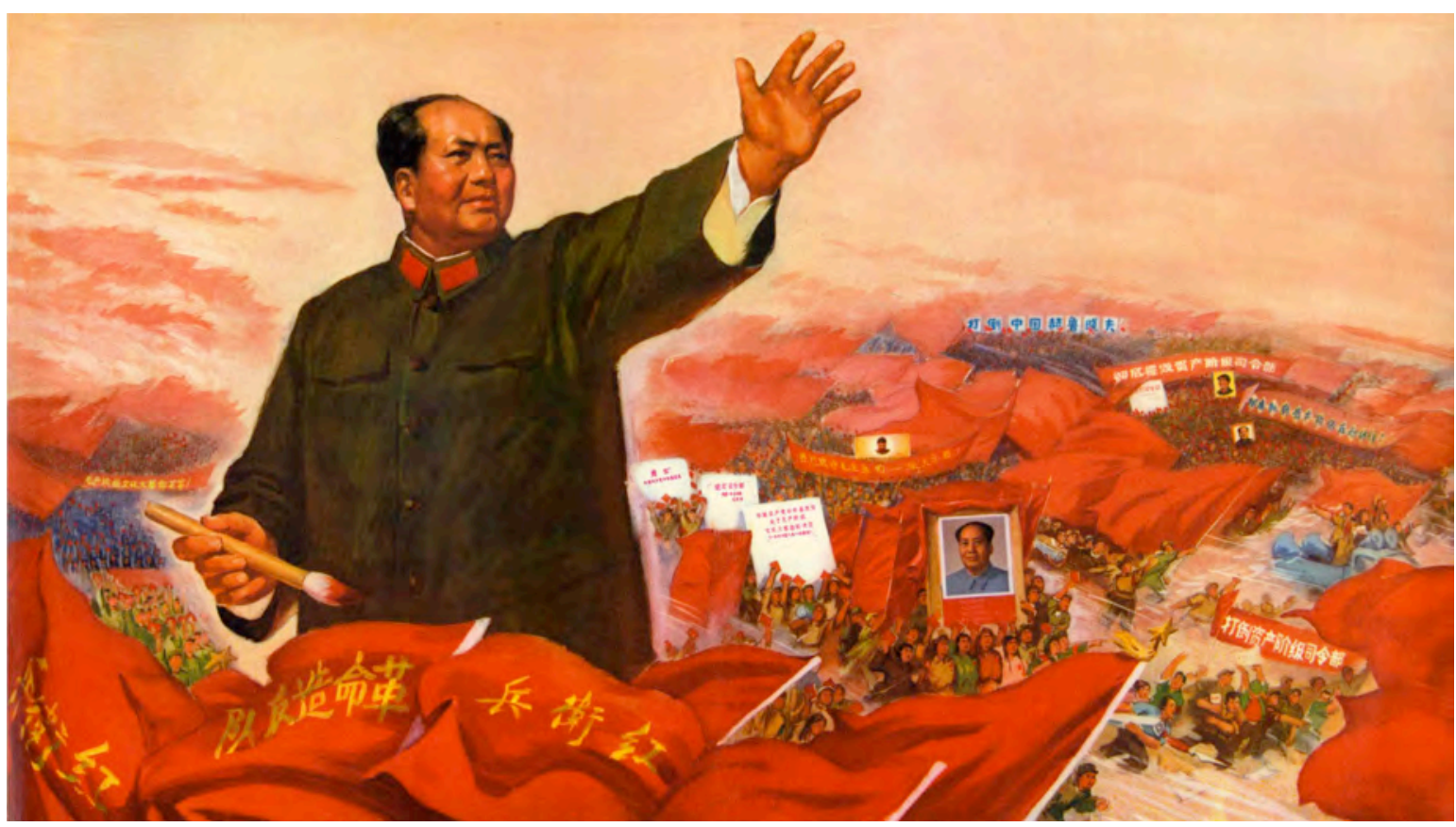

Figure 13: Poster of Mao and 'Bombard the Headquarters' c. 1967.

Source: Long Bow Archive, Boston.

Mao's poster was powerful for a number of reasons. Named as a 'big-character poster' it drew on the authority of the unofficial and rebellious. Written by the hand of the revolutionary demiurge it feed off the unofficial status of the medium while validating the role of the rebellious leader. It also employed a colourful political rhetoric that combined a modern political lexicon with historical allusion and semi-classical Chinese syntax, all of which were couched in a tone of high dudgeon. Apart from the image of the poster itself, this landscape of imagery — one that featured reds, blacks and whites, one of vituperation and metaphorical dangers and ill-concealed threat — continues to enjoy a purchase on Chinese media, politics and art to this day (Barmé 2012a).

A crucial element in the prose of Mao's poster is that he see-sawed between the resolutely martial spirit of the dominant revolutionary standing on the side of historical inevitability and the claims of a resistant underdog who was supposedly engaged in a struggle of resistance against an unyielding bureaucracy. In this 'poster,' the author portrays himself and those he supports as victims, outsiders who enjoy a purity of purpose and who are struggling to have their voices heard. Yet in a document initially written for and circulated among party leaders at a crucial moment in the country's political history, 'Bombard the Headquarters' contained powerful declamations that, through their very magisterial nature, would brook no rebuke; nor indeed did they require a defence or, for that matter, would they countenance a response (Figure 14). 


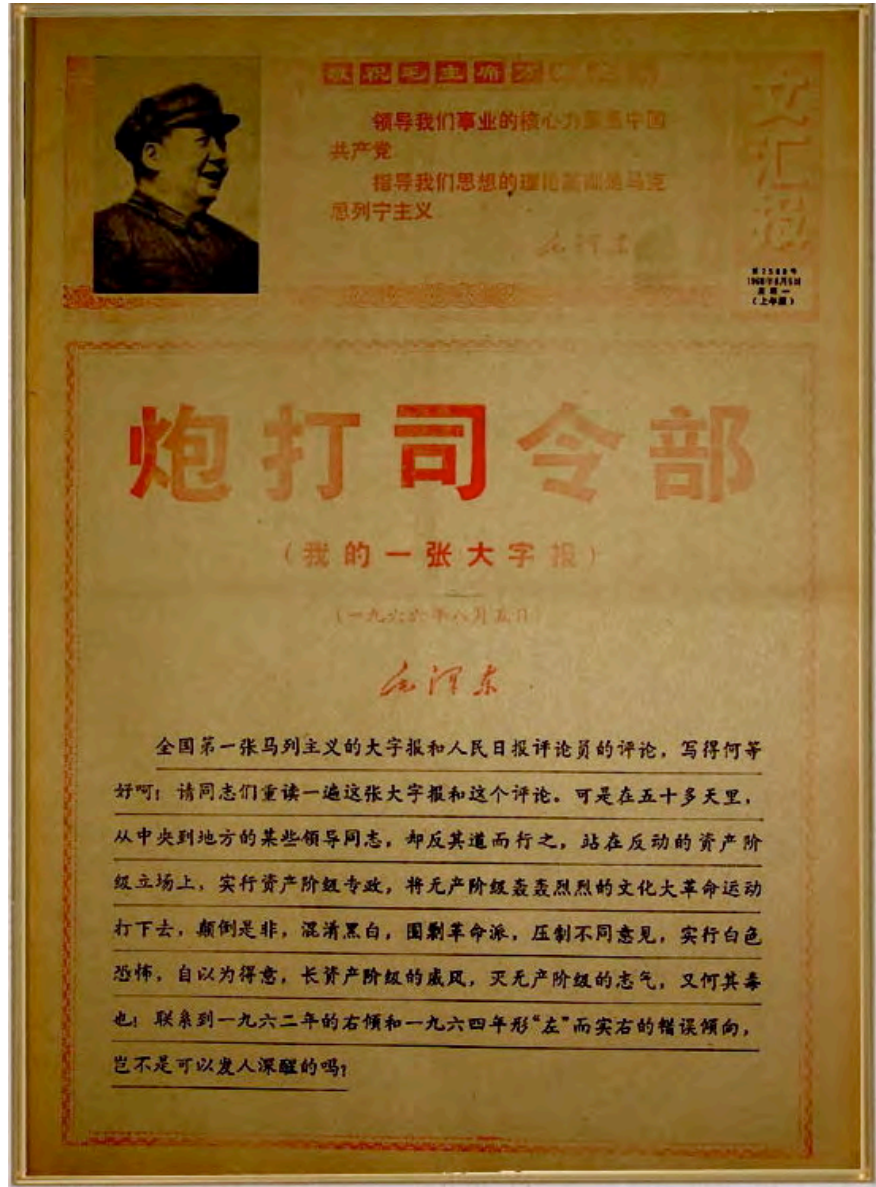

Figure 14: Text of 'Bombard the Headquarters' in a Red Guard publication, 1966. Source: Long Bow Archive, Boston.

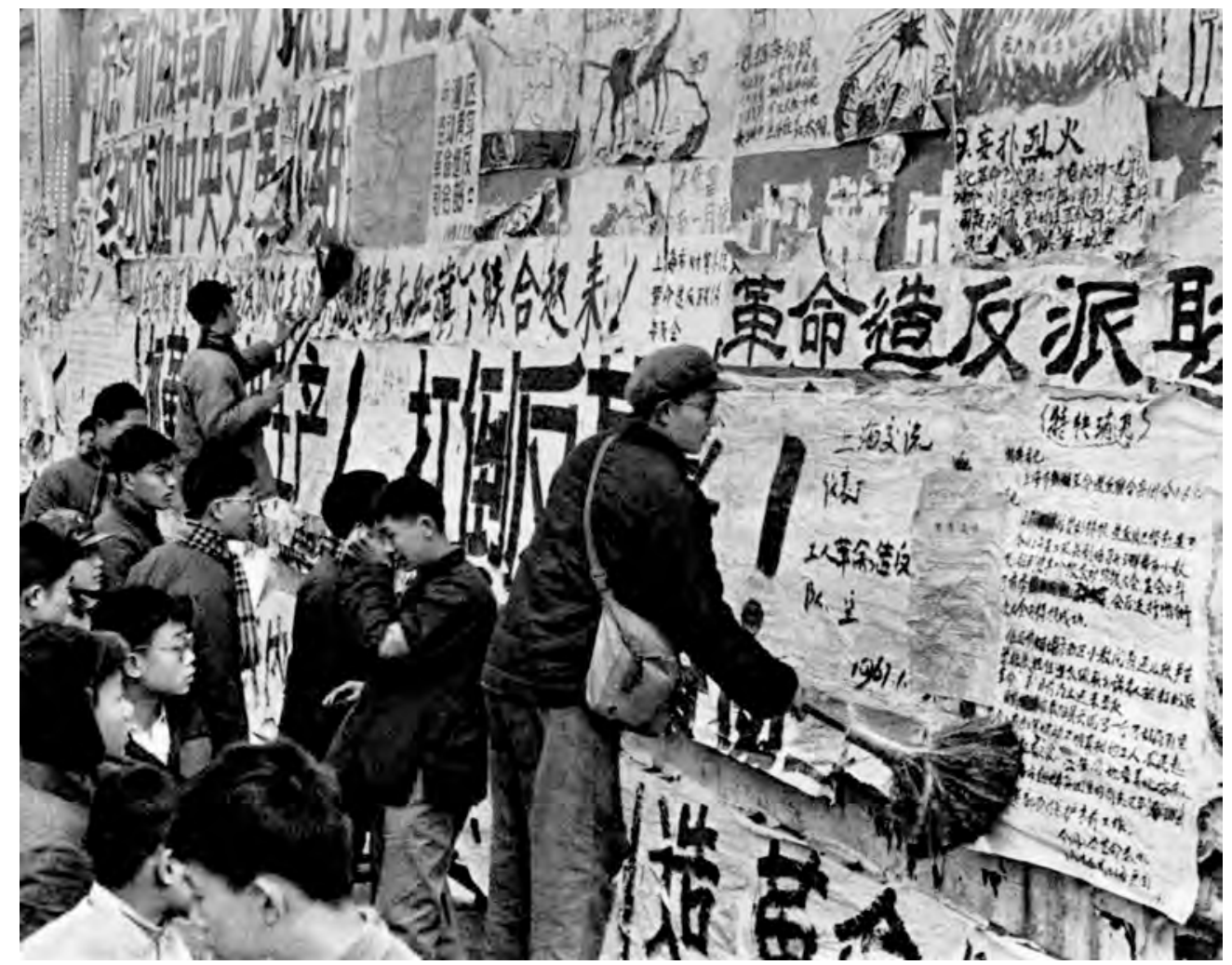

Figure 15: Red Guards and revolutionary rebels putting up posters in Beijing, 1966. Source: Long Bow Archive, Boston. 


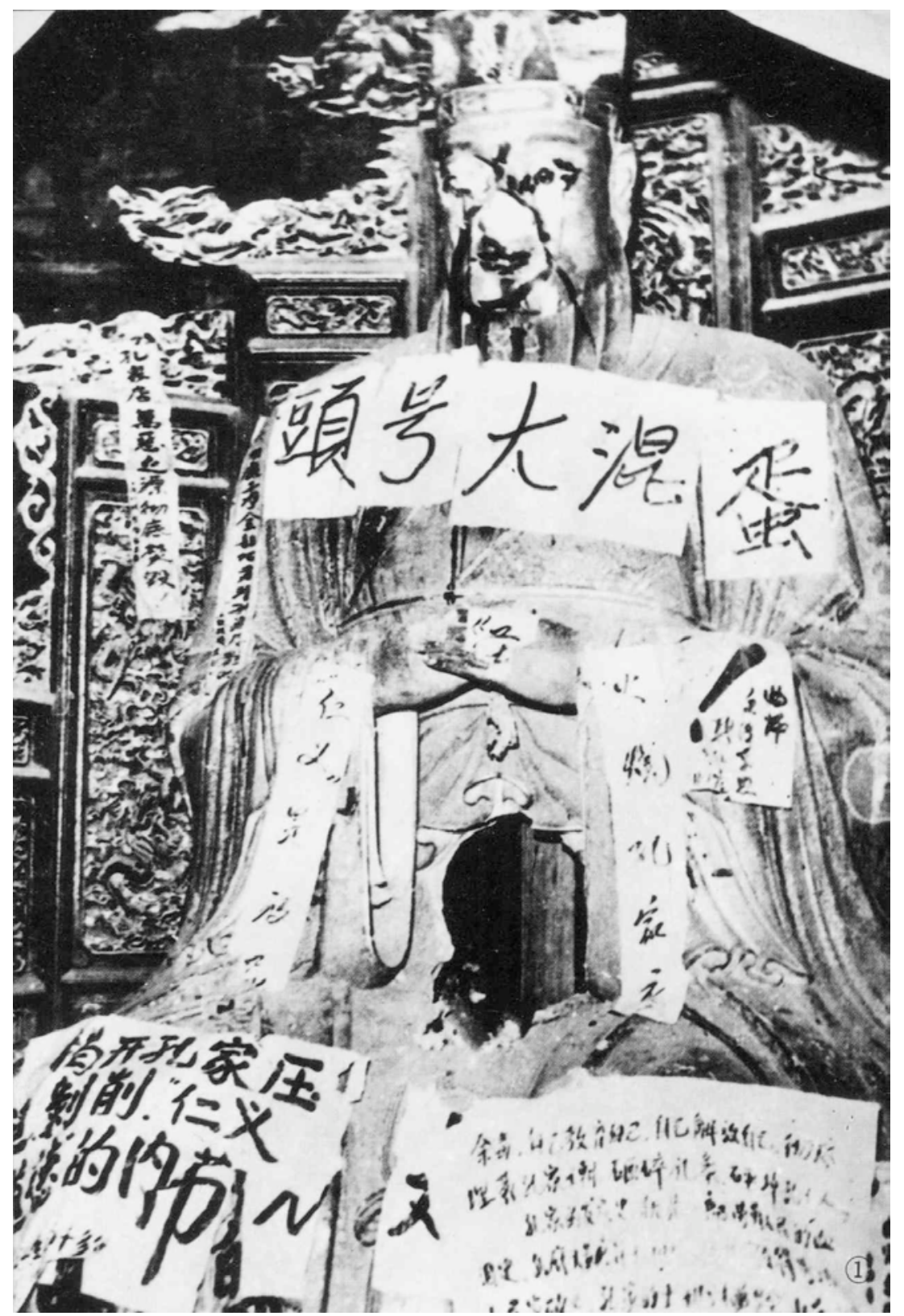

Figure 16: A poster-festooned statue of Confucius, 'the number one bad egg.' Source: Long Bow Archive, Boston.

Mao Zedong's affirmation of the Peking University big-character poster, followed by his approval of the Red Guards and the publication of 'Bombard the Headquarters' in August 1966 , led to the big-character poster becoming one of the key tools in the further radicalization of Chinese society and political discourse (Figure 15). Posters soon covered walls not only in schools and on university campuses, but also in government offices, factories, along streets, places of worship and throughout the countryside (Figure 16). From mid 1966 until late 1967, the big-character poster was a ubiquitous form of political expression, one that combined wall art with the written word and deadly political purpose (Figure 17). 


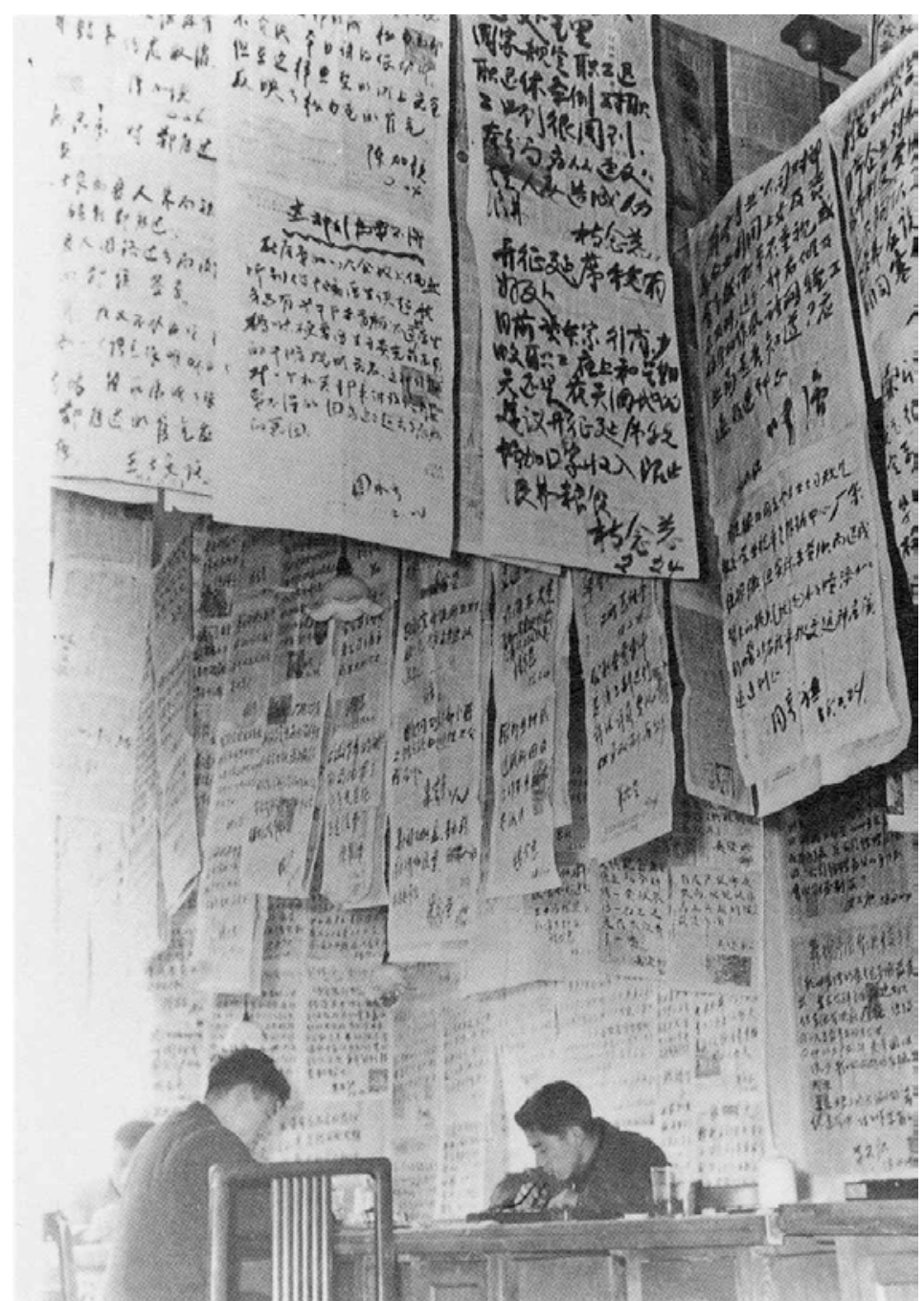

Figure 17: Big-character poster denunciations in an office, 1967. Source: Long Bow Archive, Boston.

\section{The future tragedy of Democracy Wall}

When the radical agenda of the Cultural Revolution years was eventually called into question, again the big-character poster was employed to do so. The most famous instance of written public opposition to Mao dates from 1974 when a sprawling, multipanel poster appeared on the streets of the southern city of Guangzhou. Known as the 'Li-Yi-Zhe Big-character Poster' (Li Yizhe dazibao 李一哲大字报), it called for an end to party authoritarianism and appealed for 'socialist democracy and the rule of law.' Other petitions to the government and protests against party rule appeared in the fading years of the Cultural Revolution, but the Li-Yi-Zhe poster stands out for its unstinting support for big-character posters as a form of democratic expression (the poster was the work of LI Zhengtian from the Guangzhou Art Academy, Chen YIyang, a high-school student and Wang XiZHE, a worker; they signed their joint work with the composite name Li Yizhe). 
Smaller posters featuring poems written in mourning for the deceased Premier Zhou Enlai featured fleetingly in early April 1976, when people gathered in Tiananmen Square in his memory and in protest. Again, posters were central to the popular outcry against party rule and dictatorship during the protests of 1978-1979 when a street-side wall at Xidan on Chang'an Boulevard in central Beijing became for a time the national forum for political dissent in China. The most famous of the posters pasted on what would be known as the 'Xidan Democracy Wall' (Xidan minzhu qiang 西单民主墙) was written by a young electrician by the name of Wei Jingsheng. In it Wei called for a 'fifth modernization' to be added to China's program to transform itself: democracy.

Wei's appeal for fundamental political change in China was, however, only one of the many manifestos and statements that appeared during the short-lived Democracy Wall period. Others imagined a very different, and less than democratic, future for China. As from late 1978, when the country entered a period of prolonged market-oriented economic reform and trade openness, there were those who saw change as merely an interregnum in harsh party rule.

In May 1979, a haunting story published under the penname Su Ming, entitled 'A Possible Tragedy in the Year 2000' (Keneng fasheng zai 2000 niande beiju可能发生在2000年的悲剧), appeared in the samizdat journal Peking Spring as well as on the wall at Xidan. The story was set twenty years into the future, in the last year of the old and the first year of the new century. Following the death of a number of senior political leaders in suspicious circumstances, the members of the Gang of Four (having been purged in 1976 and blamed for the violent excesses of the Cultural Revolution period) are suddenly rehabilitated.

'Another political upheaval has convulsed China,' writes Su Ming in his prophetic fiction. 'A bold supposition, perhaps, but if you look at the history of China and the weakness of her political institutions, not so totally improbable.' The story then offers a timeline:

December 26 [1999]: Celebrations of the 106th anniversary of the birth of Chairman Mao reach their climax. The People's Daily runs a front-page headline that reads: 'Our Great Teacher Chairman Mao is the Never-setting, Red, Red Sun in the Hearts of the People of the Entire World' ...

October 1: The fifty-first anniversary of the founding of the People's Republic is celebrated in grand style. The new leadership of Party Central mounts the rostrum at Tiananmen to review the parade of five million. The new leader delivers the following speech:

We must be resolute and ruthless in our efforts to exterminate the capitalists within the party; we must prevent a reoccurrence of the tragedy that took place twenty-two years ago [with the initiation of market-oriented reforms];

We must carry through the present reforms and re-establish centralized party leadership; 
We must wipe out the corrupt bourgeois Western influences that prevail in all spheres of ideology; the proletariat must occupy all fronts;

We must freeze wages and stress ideological revolution; we must limit or eliminate altogether bourgeois legal rights, and destroy the existing polarization of poverty and wealth.

We must get rid of foreign capital; we must impose strict controls on relations with foreign countries and conduct a revolutionary diplomatic policy based on self-reliance;

We must strengthen the public security system and enforce the dictatorship of the proletariat rigorously, in order to limit the activities of the bourgeoisie in every sphere. (Su Ming 1979: 137-148)

In speculative retrospect, such a refrain will be eerily familiar to readers of Utopia, the Maoist fundamentalist Internet site that flourished from 2002 up to the downfall of Chongqing Party Secretary Bo Xilai in March 2012 (Hunwick 2012). The tenor of this speech concocted by Su Ming in 1979 also adumbrates the hardline sentiments of the ficitional party leader featured in the 2008 novel The Fat Years (盛世: 中國、2013年) by the Beijing-based Hong Kong author Chan Kuan-choong (Jaivin 2010).

\section{Character assassination}

Of course, the counter-revolution that Su Ming had spoken of never occurred, at least not in the way that he had imagined. Chinese reality has outwitted even the canniest prognosticators: the country has maintained a one-party state as well as the Mao-era panoply of revolutionary language and symbolism while pursuing a radical form of partyguided neo-liberal market reform.

Big-character posters appeared fleetingly ten years after the Democracy Wall when rebellious students in Beijing called on their fellows to march on Tiananmen Square in 1989 to protest against the party following the former Party General Secretary $\mathrm{Hu}$ Yaobang's death in mid-April that year. But the poster as a political instrument and form of populist democracy had all but been eliminated following the closing down of the Xidan Democracy Wall in 1979. Indeed, big-character posters were formally banned by the Chinese government in September 1980 on the grounds that history had proven they were unable to contribute positively to the growth of 'popular democratic rights in China.'

During the decade from 1979 until 4 June 1989, art as much as internal party contestation and academic polemics was the arena in which some of the most powerful protean energies harboured through the Cultural Revolution years were to find expression. In particular, artists engaged with the written Chinese character, the Hanzi 汉字, to investigate the residual power of text and image. Using a form of orthography that 
contained strong visual and symbolic elements, they turned the written word, the text itself, into the basis for their artistic experimentation. They attempted thereby both to lambast and to challenge the world of words, the plethora of propaganda and the empire of signs that had bedevilled so many writers and thinkers in China's twentieth century. Artists turned the written and printed word into a palette for their own cultural recreations. They did so through an interrogation of and assault on the Chinese character itself.

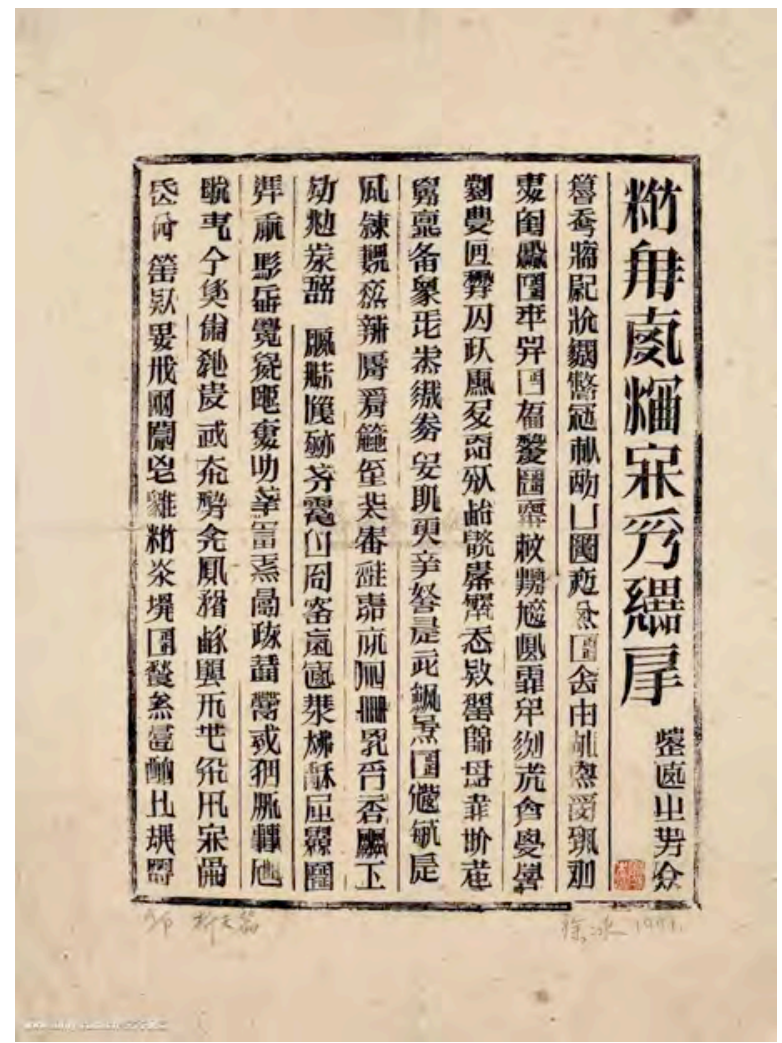

Figure 18: A page from Xu Bing's 'Book from the Sky.' Source: Gao Minglu (2008) '85 Meishu Yundong-80 niandaide renwen qianwei, Guangxi shifan daxue chubanshe, Guilin, vol. 1.

Many of these efforts and investigations into the written, the spoken and the visual focussed on the ideas of wei 伪 (the false, non-legitimate, fake, imitation, corrupt, madeup, invented) as opposed to zhen 真 (the true, correct, accurate, appropriate, real). In the 1980s, some artists pursued their investigation through meticulous artisanship, as was the case in Beijing of Xu Bing, famous for creating with a group of wood-block carvers his 'Book from the Sky' (Tianshu 天书) (Figure 18, above).

Others pursued the subject in Hangzhou, one of the alternate centres of artistic production near Shanghai. A prominent early figure in this latter group was Gu Wenda whose work 'Displacement' (Cuowei 错位) and his continued assault on Chinese characters garnered 
him early fame (Figure 19). Then there were such non-academy trained creators as

Manchu-Chinese Guan Wei, whose work has been familiar to Australian audiences since the early 1990s. As early as the mid-1980s, Guan used his art to tussle with the nonsense of Chinese literary clichés in the context of acupuncture and anomie (Guan Wei 1988: 387ff) (Figure 20).

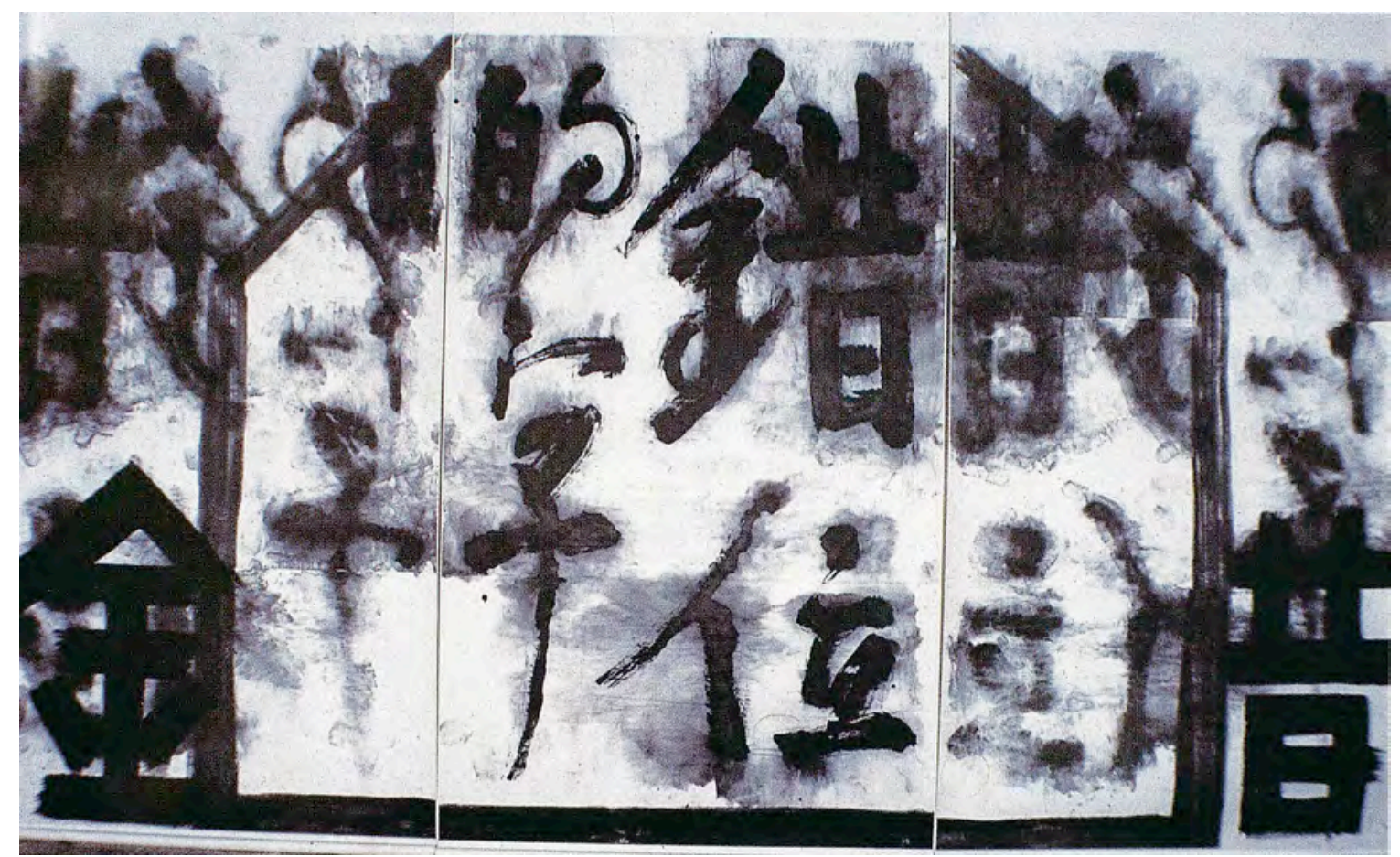

Figure 19: 'Displacement,' Gu Wenda. Source: Gao Minglu (2008) '85 Meishu Yundong_80 niandaide renwen qianwei, Guangxi shifan daxue chubanshe, Guilin, vol. 1.

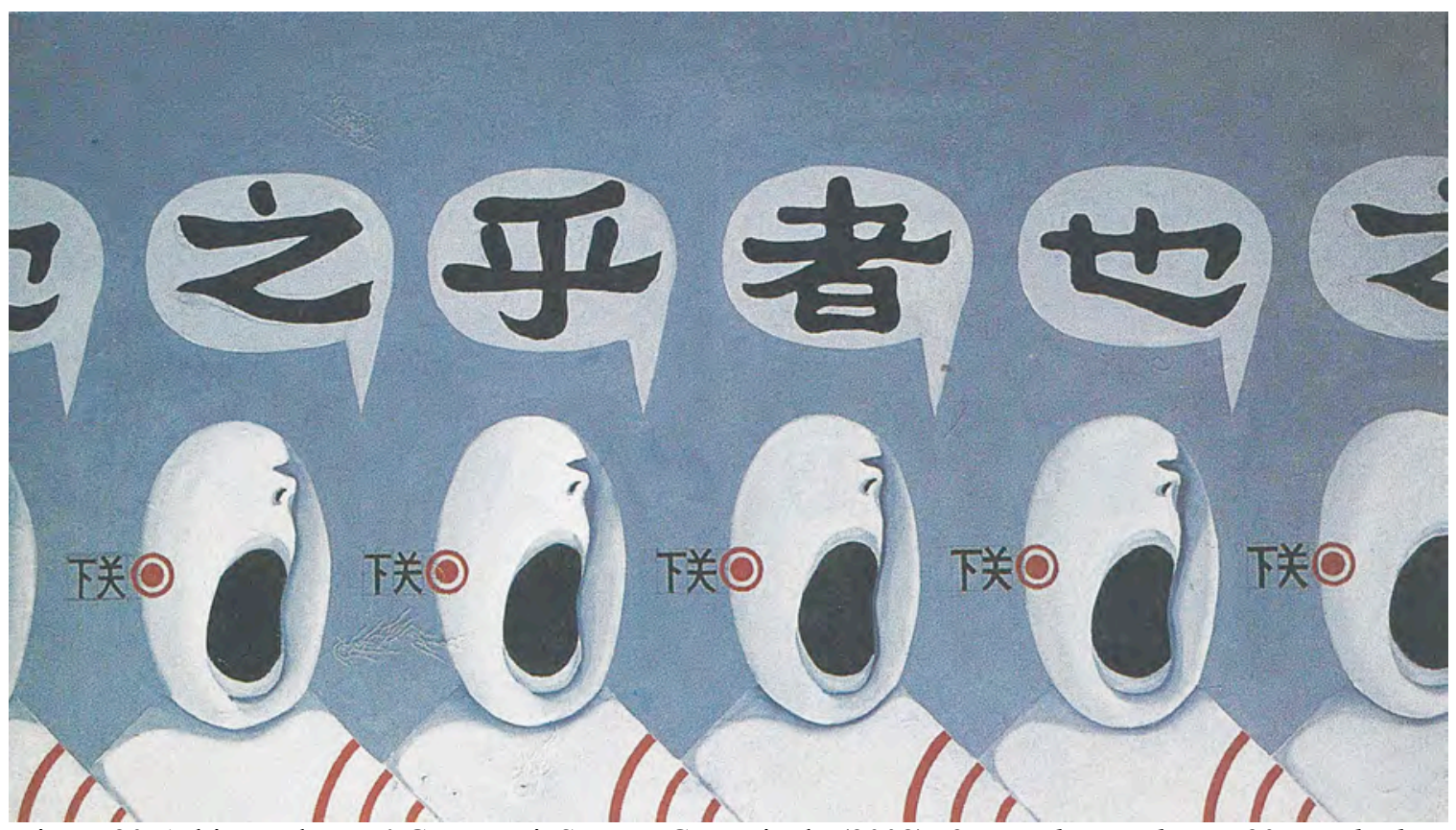

Figure 20: 'Zhi Hu Zhe Ye,' Guan Wei. Source: Gao Minglu (2008) ’85 Meishu Yundong_80 niandaide renwen qianwei, Guangxi shifan daxue chubanshe, Guilin, vol. 1. 
Another artist in the milieu of $\mathrm{Gu}$ Wenda was $\mathrm{Wu}$ Shanzhuan, mentioned at the beginning of this paper (Wu 2008: 6-7). Originally from Zhoushan near Shanghai he too was trained in Hangzhou. This was a period in which groups of artists and poets flourished in the People's Republic and they collectively began challenging and changing the face of contemporary Chinese art and culture through grandiose manifestos, sententious samizdat publications, performance pieces and guerrilla exhibitions. After graduating from art school he returned to Zhoushan where, with a number of fellow graduates, he established an artistic collective called 'Red Humor' at the local Zuyin Temple in February 1986.

The 'Red Humor' group claimed their works gave expression to 'serious absurdity' (yansude huangdan 严肃的荒诞). In particular, they were obsessed with the written Chinese character - something they took as being a concrete embodiment of the artistic, the cultural and the ideological. Their first exhibition was titled 'Red 70\% Black 25\% White 5\%'; among other things it featured the word 'nirvana' (niepan 涅磐) that was placed over a pile of symbols that spelled out 'garbage' (laji 垃圾). Through their use of oversized, distorted and higgledy-piggledy characters the artists employed what they called 'red humor' to question the faded red of China's revolution and the deficit of meaning in they found in the often-ludicrous party-state propaganda of their day.

Theirs was an artistic observation on the state of contemporary culture as well as an attempt to adjudicate over the past. For his part, Wu Shanzhuan also made a series of red seals, of the kind used instead of a signature and for notarizing documents. He declared that the oversized seals were represented the imprimatur of his group, the 'In the Red Revolutionary Committee' (Gao 2008, 1: 224-35).

In 1987, Wu created an installation called 'In the Red' (Chizi 赤字) (Osnos 2009). It featured a room covered in the graffiti-like remnants of big-character posters, as well as randomly written signs and lines made up by himself and others. In this work $\mathrm{Wu}$ attempted to manufacture in a reduced form the stifling environment of the written logorrhoea of the past; it was an ironic attempt to recapture the overwhelming and manic mood engendered by the red sea of big-character posters that swelled up from mid 1966, which we have discussed in the above (Figure 21). 


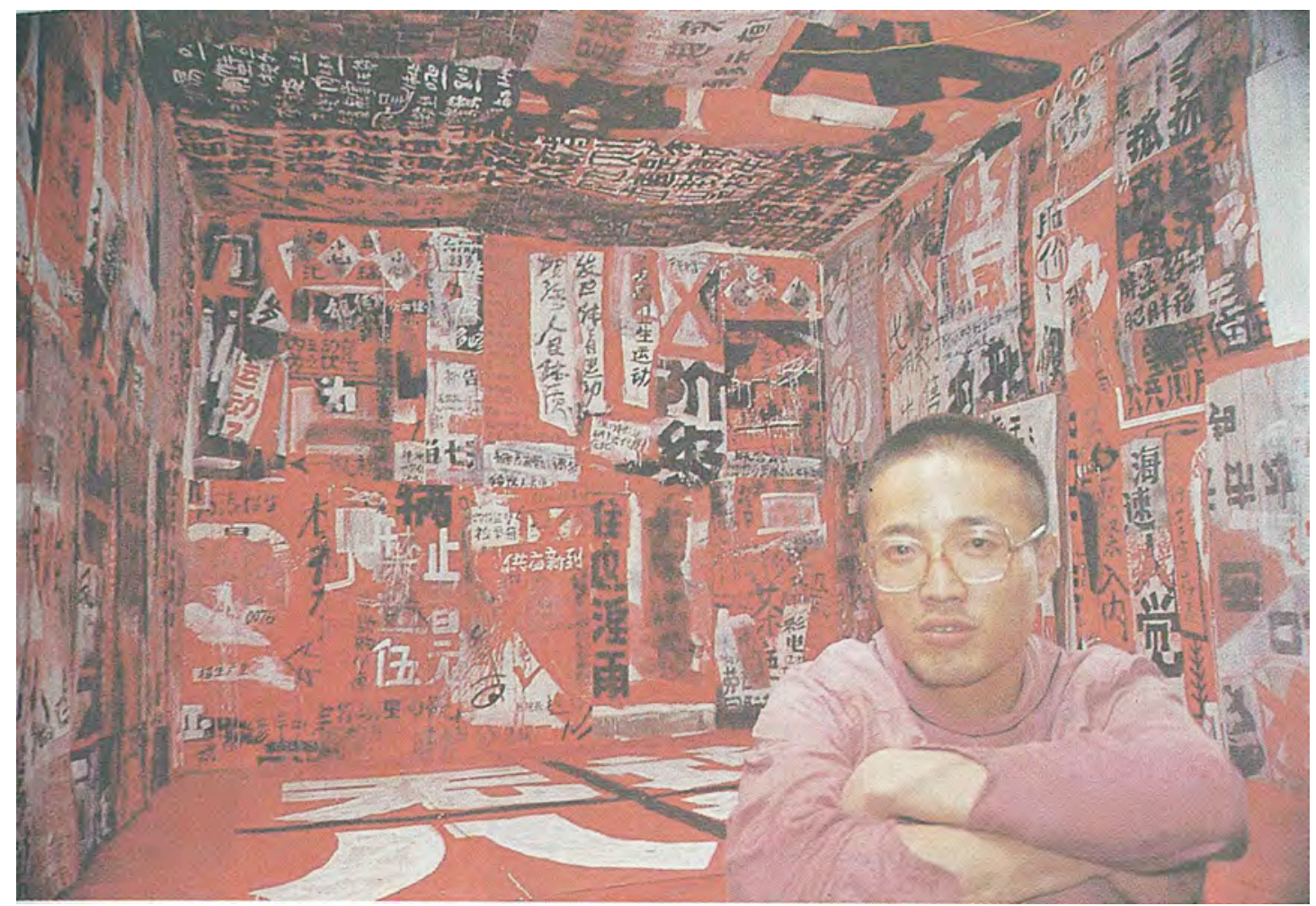

Figure 21: Wu Shanzhuan and 'Red Humor.' Source: Gao Minglu (2008) '85 Meishu Yundong_80 niandaide renwen qianwei, Guangxi shifan daxue chubanshe, Guilin, vol. 1.

As an ironic reprise of big-character poster culture, 'Red Humor' and 'In the Red' were a shorthand reprise of the big-character posters that played a crucial role in the culture and politics of the Cultural Revolution era. In the bapo Eight-fragments style of these installations, a simple quotation of verbal extremism and abuse, Wu Shanzhuan offered a momentary reflection on the word, the wall and the maelstrom of the revolutionary excess, as well as the verbal outpourings of the period. In surrounding the viewer with disjointed quotations from the written cacophony of the character poster, $\mathrm{Wu}$ left the viewer with a sense of form while evacuating all actual content from what had been during the Maoist decades from the 1950s until 1980 a potent element of public politics (Figure 22). In his

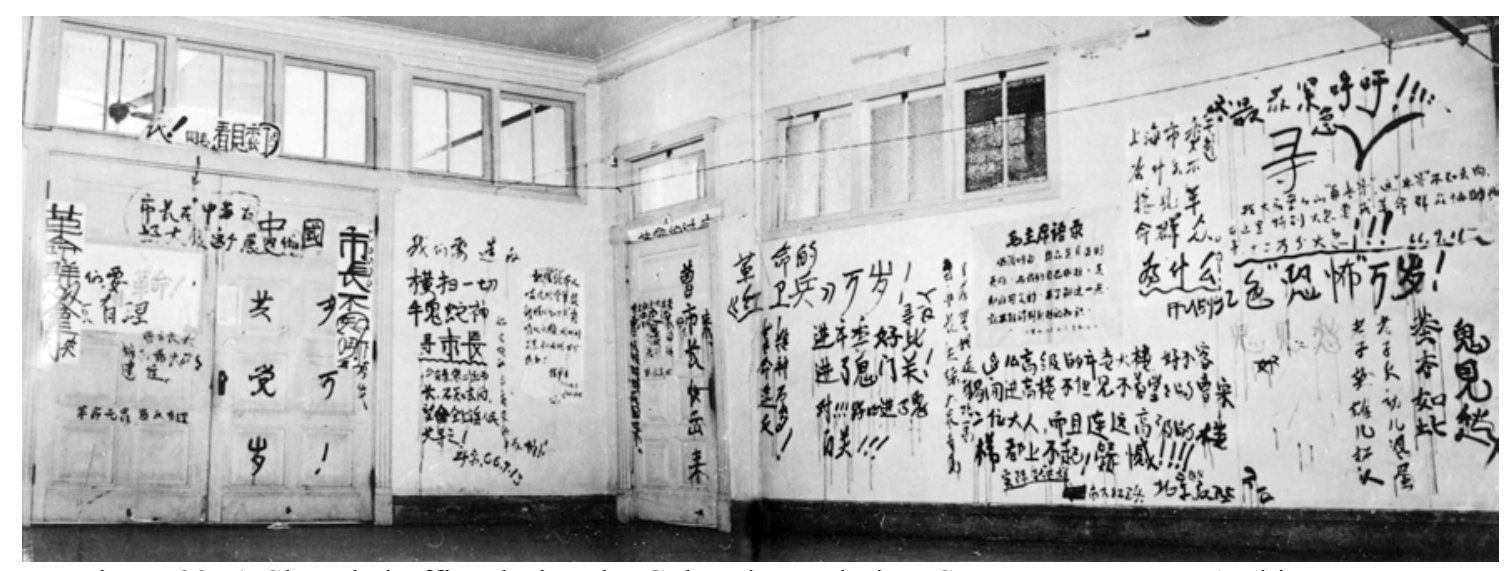

Figure 22: A Shanghai office during the Cultural Revolution. Source: Long Bow Archive, Boston. 
work, $\mathrm{Wu}$ reduced what was a complex and unique medium, one that allowed for the articulation of vastly different views and rhetorical effects, to little more than cultural wallpaper. Inadvertently, Wu's comic take on the big-character poster tells us little about the past, but a great deal about the future of China's red culture. Herein tragedy was repeated first as farce, but then again as product.

\section{Grass-mud horses}

The events of 1989, a year during which a mass protest movement from April to June would be repressed by military force in Beijing and other Chinese cities, led to a period in which artistic endeavour returned to the margins and the underground. Following the suppression of 4 June, cultural endeavours took new directions, both underground, as an alternative to the state over-culture, and in the complicity of some artists with the Communist Party's market socialism (Barmé 1999). The artistic tussle with the Chinese written character and the word, however, continued. New waves of economic liberalization unleashed after 1992 as a result of the party leader Deng Xiaoping's declaration that development was China's only way to a prosperous the future had a profound impact on the urban landscape. Vast building projects in cities throughout the country saw old structures demolished and traditional neighbourhoods flattened. Walls and buildings now sported not posters of protest, but the ubiquitous word 'demolish' (chai 拆). So constant was the frenzy for demolition and reconstruction that eventually one wag created a composite character 'chai-na' 拆十那, which combined the word 'demolish' with the syllable $n a$ (Figure 23). 'China' was now the place where 'things are being torn down' (chai ne 拆呢).

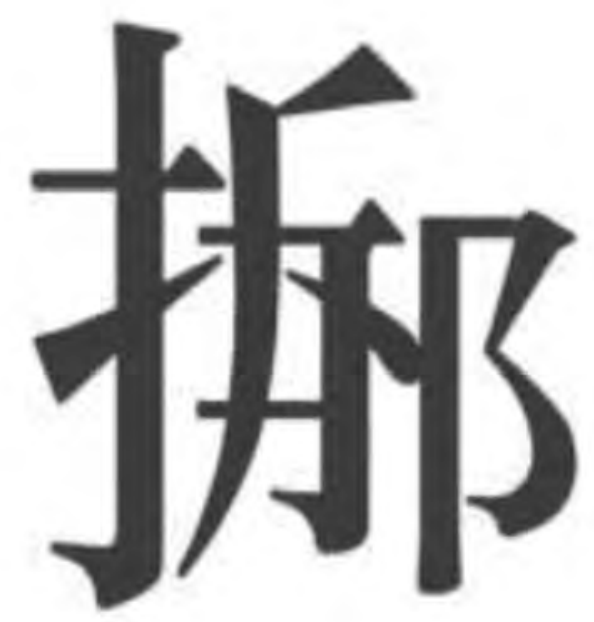

Figure 23: The composite character 'chai-na' 拆+ 那. 
Online comics also took pleasure in creating playful new Chinese characters. Another combination character was 'diang', which melded the three words dang 党 + zhong 中 + yang 央, or 'Central Committee of the Chinese Communist Party' (Figure 24). But the war of words was not limited to orthographic inventions. The resistance to the constant outpourings of party propaganda, a veritable red logorrhoea, was often far more pointed.

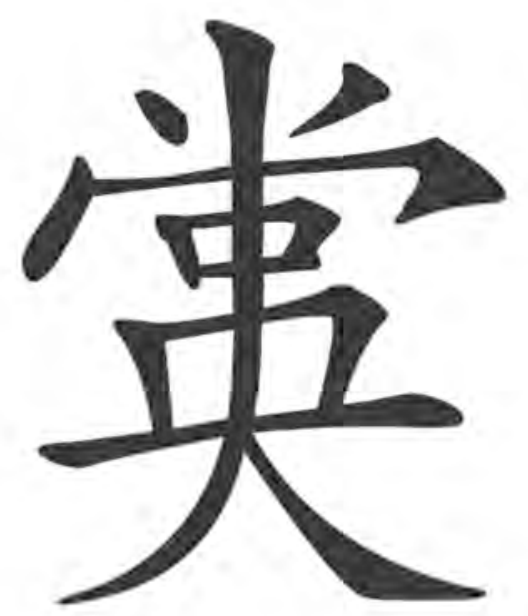

Figure 24: 'Diang': dang 党 + zhong 中 + yang 央, or 'Central Committee of the Chinese Communist Party.'

In 2009, an Internet meme appeared in the form of the Grass-mud Horse (Caonima 草泥 马) (Figure 25). Featured in a comic video the 'horse' bore a name that was a play on the words cào $n \check{~} m \bar{a}$ 食你妈, literally 'fuck your mother.' It was a foul-mouthed attack on the tireless efforts of the country's Internet police to censor unacceptable posts on the web. The use of a version of what, since the Republican era (1912-1949), has been dubbed 'China's national swearword' (guoma 国骂), was a pointed attack on the party-state itself.

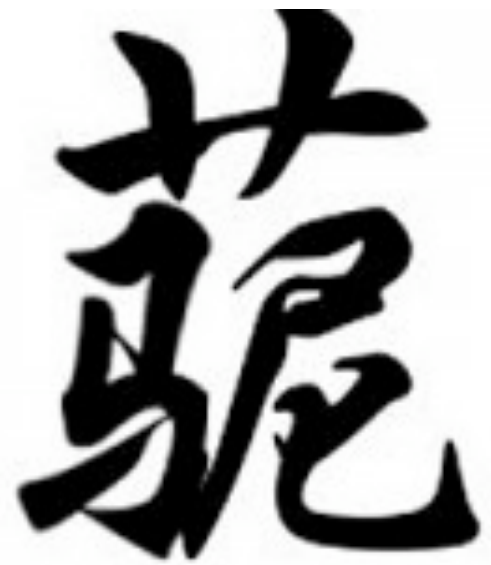

Figure 25: The composite character Grass-mud Horse (Caonima 草泥马). 
The Grass-mud Horse - a creature with the appearance of an Alpaca—was said to roam the Mahler Gobi Desert (malege bi 妈了个逼—that is, 'curse your mother's cunt') and its existence was supposed to be endangered by ravenous River Crabs (hexie 河蟹), creatures whose name is a pun on the word 'harmonize' (hexie 和谐), a term that in Chinese Internet parlance means to censor or delete unacceptable online content. Both horses and crabs were said to compete for the precious fodder known as wo cao 我操 (fuck me!).

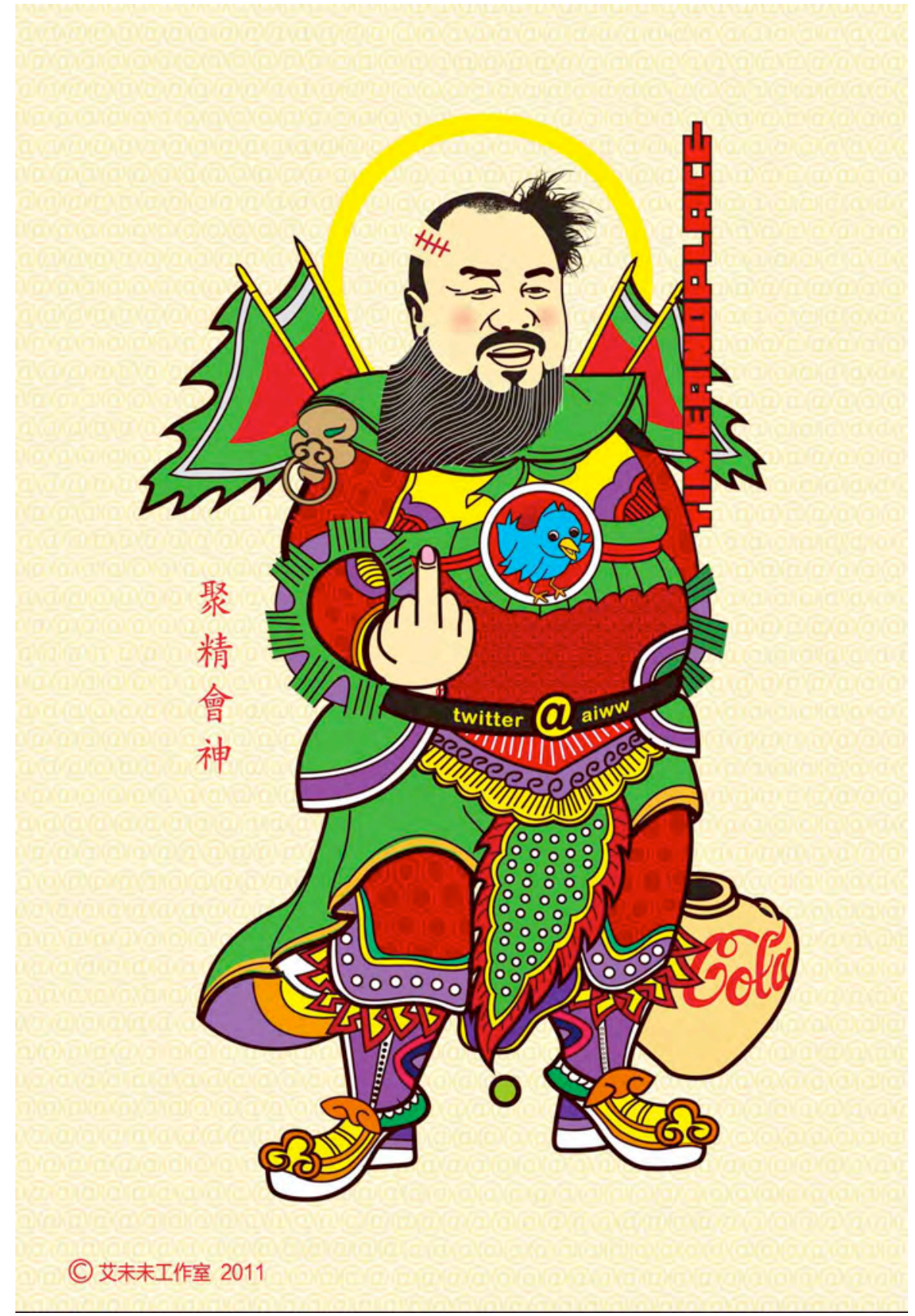

Figure 26A: Ai Weiwei as a door god. Source: Ai Weiwei Studio.

That same year the dissenting artist and blogger Ai Weiwei offered his view of the significance of the Grass-mud Horse: 
Sixty years have passed and we still haven't seen a vote, there is no universal education, no health insurance, no free press, no freedom of speech, no freedom of information, no freedom to relocate, no independent judiciary, there are no public watchdogs, no independent labor unions, no national army, no constitutional protections, and all that's left is a Grass Mud Horse. (Lee 2011: 232-33)

Following a period of detention in 2011 on charges of tax evasion, Ai soon reappeared on the Beijing arts scene subdued but not cowed. Shortly thereafter, he celebrated the indomitable spirit of the Grass-mud Horse in a series of works in the style of Chinese New Year prints (Barmé 2012b) (Figures 26A \& 26B). In the 2012 documentary film about Ai, Never Sorry, the curse word, and various permutations of it, once more features

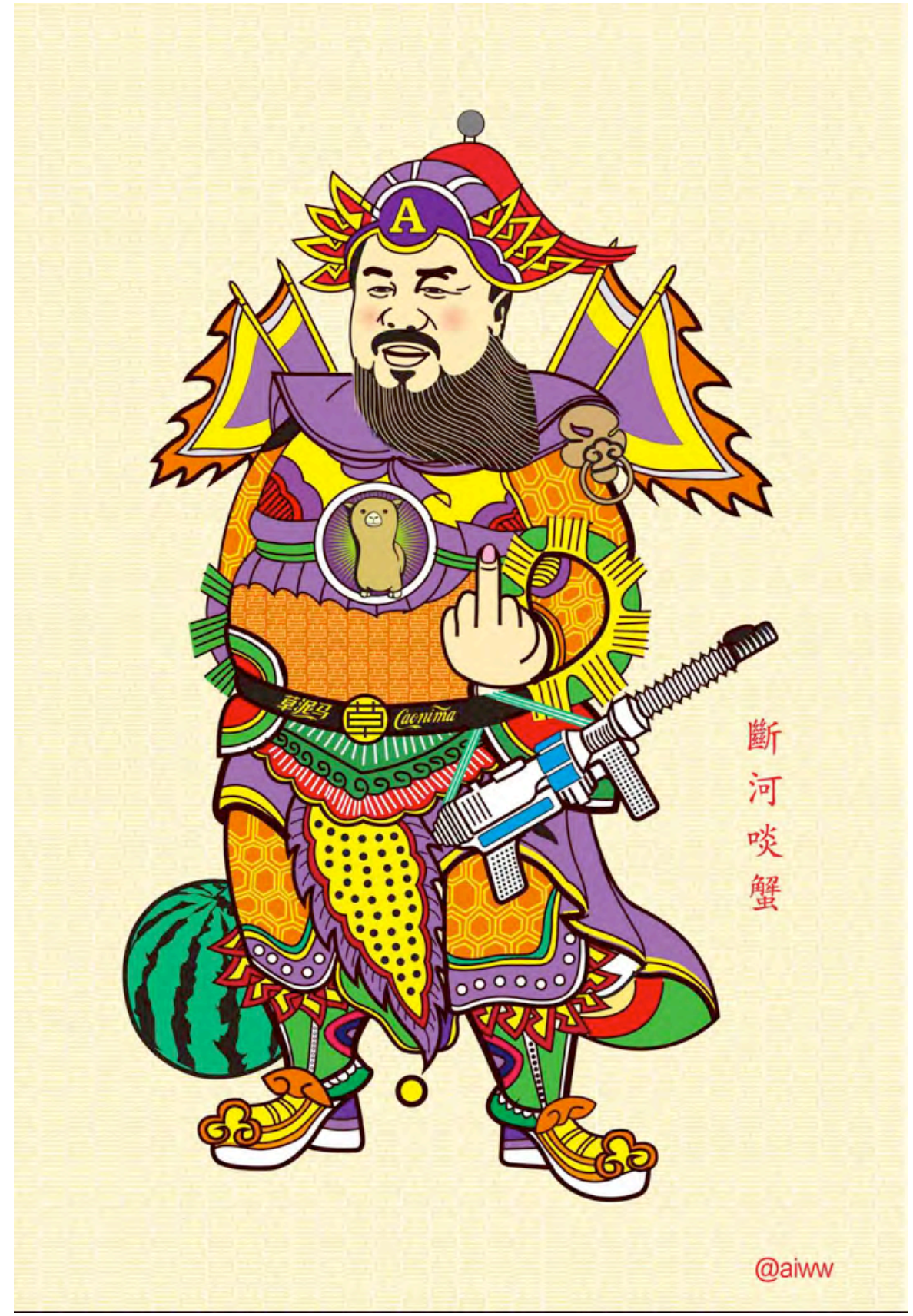

Figure 26B: Ai Weiwei as a door god. Source: Ai Weiwei Studio. 
prominently, as well as being the theme of a ditty that Ai sings to his iPad during the film's closing sequence (Klayman 2012).

This essay has argued that the tussle with the written word has been a feature of artistic endeavour, creation, deconstruction and contestation since the late-Qing era in the nineteenth century. Throughout the twentieth and into the twenty-first centuries many artists, writers and thinkers have grappled with the allure and power of the 'box-shaped character' (fangkuaizi 方块字). They have regarded it as crystallising and expressing the contradictory legacies and burdens of tradition. Manipulation of the character continues in official and non-official cultural pursuits and, in some cases, it explodes its bindings in a shower of expletives, as in the case of the foul-mouthed and artful wordsmith Ai Weiwei. In these simple slogans of disgust, contempt and rejection the word-wars of the past are summed up with crude simplicity. In three Chinese words the loathing for politics, the market and marketable protest finds its most succinct expression. A large history is, with this succinct malediction, writ small.

In concluding her comments on The Mad Box exhibition at the Art Gallery of New South Wales, with which I began this essay, Elizabeth Farrelly made the following observation about the vacuity of contemporary artistic pursuit:

This is no longer art as satire, social indictment or revelation. It's a smokescreen for a self-serving, intellectually vacant and morally abdicant curatariat.

It's not that we don't have issues. Imagine what Beckmann and Dix could do with Europe selfimmolating over money and race. With bank bailouts as houses and jobs go down the toilet. With children overboard.

Now, as Roth noted in 1933, 'the European mind is capitulating ... out of weakness ... sloth ... apathy ... lack of imagination.' We, however, preferring an optimism blinder than any of Dix's warwounded, daren't look. So our art no longer serves truth but bullshit.

\section{Acknowledgements}

This is a revised version of a keynote address given at the 'Word \& Image, East and West' conference at the Art Gallery of New South Wales, Sydney, Australia, 29 October 2011. My thanks to Maurizio Marinelli for his invitation to participate in that conference, and to write this essay for PORTAL. I am also grateful to the two anonymous readers of the revised essay for their helpful suggestions. This text is one of a series of essays and works related to 'red revivalism' in contemporary China. The others are: 'New China Newspeak, Xinhua Wenti 新华文体,' in China Heritage Quarterly, no. 29 (March 2012), online, available: http://www.chinaheritagequarterly.org/glossary.php?searchterm $=029$ xinhua.inc\&issue $=029$; 'Red Allure and the Crimson Blindfold,' in the special issue 'Mao Today: A Political Icon for an Age of Prosperity,' China Perspectives, February 2012: 29-40; and, the introductory and concluding chapters of 
China Story Yearbook 2012: Red Rising, Red Eclipse, edited by Geremie R. Barmé et al., Australian Centre on China in the World, Canberra, 2012, online, available: www.thechinastory.org.

\section{Reference List}

Ambrozy, L. (ed.) 2011, Ai Weiwei's Blog: Writings, Interviews, and Digital Rants, 2006-2009. MIT Press, Cambridge, MA: 232-33.

Barmé, G. R. 1999, In the Red, on Contemporary Chinese Culture. Columbia University Press, New York. 2012a, 'New China Newspeak,' China Heritage Quarterly, no. 29 (March). Online, available: http://www.chinaheritagequarterly.org/glossary.php? searchterm $=029$ xinhua.inc\&issue $=029$ [accessed 10 October 2012]. 2012b, China Story Yearbook 2012: Red Rising, Red Eclipse. Australian Centre on China in the World, ANU, Canberra. Online, available: www.thechinastory.org [accessed 10 October 2012].

Berliner, N. 1992, 'The Eight Brokens, Chinese Trompe l'Oeil Painting,' Orientations, February: 61-70.

Chinese Literature 1966. 'Salute to the Revolutionary Young People!,' no. 11: 42-43.

Farrelly, E. 2011, 'When Art Had its Eyes Wide Open,' Sydney Morning Herald, 27 Oct. Online, available: http://www.smh.com.au/opinion/society-and-culture/when-art-had-its-eyes-wide-open20111026-1mjzn.html\#ixzz1bx0jEhkM [accessed 10 October 2012].

Gao Minglu. 2008, '85 Meishu Yundong-80 niandaide renwen qianwei, vol. 1. Guangxi shifan daxue chubanshe, Guilin: 224-35.

Guan Wei. 1988, images in Seeds of Fire: Chinese Voices of Conscience, (eds) G. R. Barmé \& J. G. Minford. Hill \& Wang, New York: 40, 387, 392, 396, 399, \& 404.

Hunwick R. F. 2012, 'Fan Jinggang 范景刚.' Online, available: http://www.thechinastory.org/intellectuals/fan-jinggang-范景刚/ [accessed 10 August 2012].

Jaivin L. 2010, 'Yawning Heights: Chan Koon-chung's Harmonious China,' China Heritage Quarterly, no. 22 (June). Online, available:

http://www.chinaheritagequarterly.org/articles.php? searchterm $=022$ golden.inc\&issue $=022$ [accessed 10 October 2012].

Klayman, A. (dir.) 2012, Never Sorry, United Expression Media, documentary film.

Kraus, R. 1991, Brushes with Power: Modern Politics and the Chinese Art of Calligraphy. University of California Press, Berkeley.

Ledderose, L. 1979, Mi Fu and the Classical Tradition of Chinese Calligraphy. Princeton University Press, Princeton, NJ.

Li Rui. 1998, Mao Zedongde zaonian yu wannian. Guiyang: Guizhou chubanshe: 290.

Mao Zedong. 1967, 'Bombard the Headquarters-My Big-character Poster,' Peking Review, no. 33, 11 March (with modification). 1976, 'Qilü-he Guo Moruo tongzhi,' translated as 'Reply to Comrade Kuo Mo-jo-a lü shih, November 17, 1961,' in Mao Tsetung, Poems. Foreign Languages Press, Beijing: 41 (spelling modified).

Murck, A. \& Wen Fong (eds) 1991, Words and Images: Chinese Poetry, Calligraphy and Painting. Metropolitan Museum of Art, New York; Princeton University Press, Princeton, NJ.

Osnos, E. 2009, 'Letter from China: Wu Shanzhuan and Hans Ulrich Obrist,' 11 November. Online, available: http:/www.newyorker.com/online/blogs/evanosnos/2009/12/wu-shanzhuan-and-hansulrich-obrist.html [accessed 4 May 2012].

Su Ming. 1979, 'A Possible Tragedy in the Year 2000,' Beijing Spring, May. This translation is taken from 'Lingering Fear,' in Seeds of Fire: Chinese voices of conscience, (eds) G. Barmé \& J. Minford, $2^{\text {nd }}$ ed. New York: Hill \& Wang, 1988: 137-48 (with modification).

Wu Hung. 2008, Making History: Wu Hung on Contemporary Art, Hong Kong, Time Zone 8.

Xiao Gongqin. 2012, Chaoyue zuoyou jijinzhuyi_zouchu Zhongguo zhuanxingde kunju (Overcoming the Extremism of Left and Right). Zhejiang daxue chubanshe, Hangzhou. 